\title{
A LEGISLATOR'S GUIDE TO MUNICIPAL SOLID WASTE MANAGEMENT
}

Deb Starkey and Kelly Hill

Energy, Science and Natural Resources Program

\author{
National Conference of State Legislatures \\ William T. Pound, Executive Director
}

1560 Broadway, Suite 700

Denver, Colorado 80202

444 North Capitol Street, N.W., Suite 515

Washington, D.C. 20001

August 1996

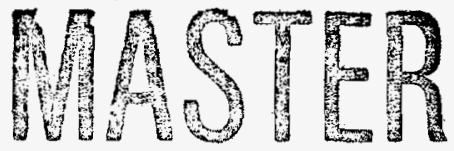




\section{A \\ IIII}

The National Conference of State Legislatures serves the legislators and staffs of the nation's 50 states, its commonwealths and territories. NCSL is a bipartisan organization with three objectives:

- To improve the quality and effectiveness of state legislatures,

- To foster interstate communication and cooperation,

- To ensure states a strong cohesive voice in the federal system.

The Conference operates from offices in Denver, Colorado, and Washington, D.C.

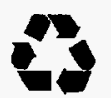

Printed on recycled paper

(c)1996 by the National Conference of State Legislatures. All rights reserved.

ISBN 1-55516-519-2 


\section{DISCLAMMER}

Portions of this document may be illegible in electronic image products. Images are produced from the best available original document. 


\section{DISCLAIMER}

This report was prepared as an account of work sponsored by an agency of the United States Government. Neither the United States Government nor any agency thereof, nor any of their employees, makes any warranty, express or implied, or assumes any legal liability or responsibility for the accuracy, completeness, or usefulness of any information, apparatus, product, or process disclosed, or represents that its use would not infringe privately owned rights. Reference herein to any specific commercial product, process, or service by trade name, trademark, manufacturer, or otherwise does not necessarily constitute or imply its endorsement, recommendation, or favoring by the United States Government or any agency thereof. The views and opinions of authors expressed herein do not necessarily state or reflect those of the United States Government or any agency thereof. 


\section{CONTENTS}

Preface and Acknowledgments ...........................................................................................

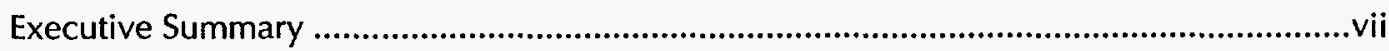

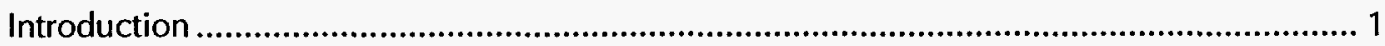

Current Municipal Solid Waste Management Issues That Affect States ................................. 2

Nature and Extent of the Municipal Solid Waste Management Issue ................................... 4

Integrated Municipal Solid Waste Management .............................................................6 6

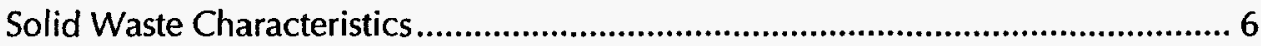

Management Approaches ................................................................................... 8

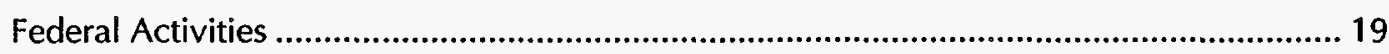

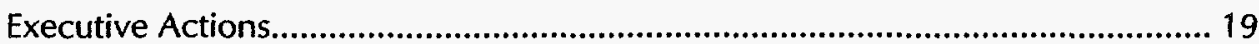

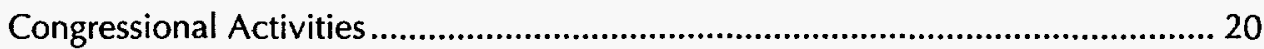

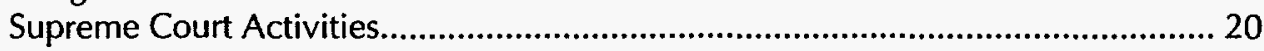

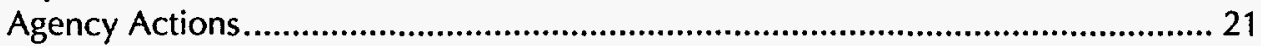

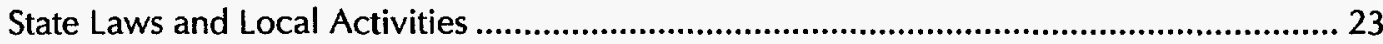

State and Local Planning Requirements .................................................................. 23

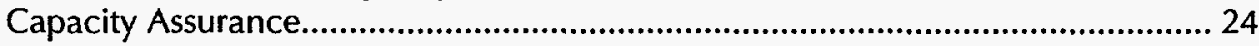

Management Costs.............................................................................................. 24

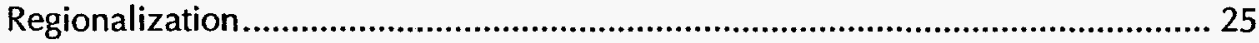

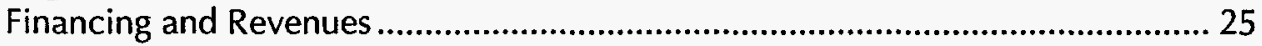

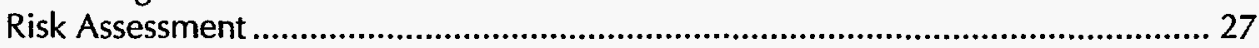

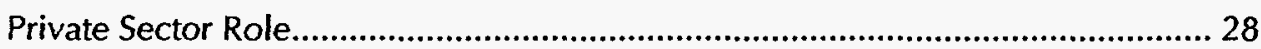

Public Involvement and Acceptance.................................................................. 28

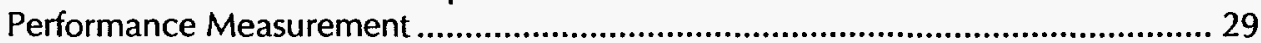

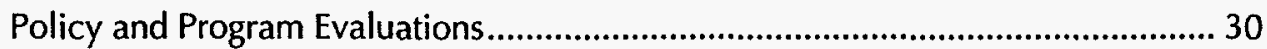

Management of Special Wastes ..................................................................... 31

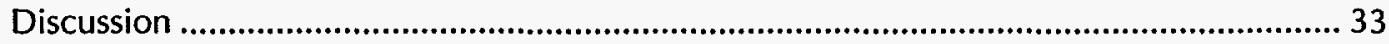

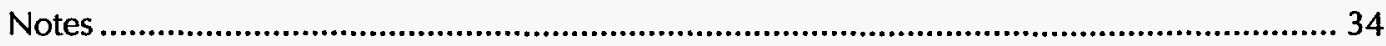



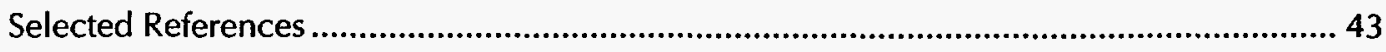

Selected Trade Publications and On-Line Resources.................................................... 47

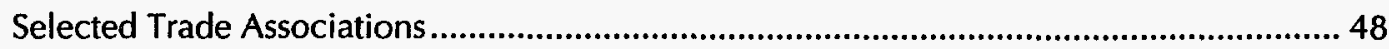


Figures

Figure 1 Products Generated in MSW, by Weight, 1994

Figure 2 Percentage of Waste Managed, by Method.

Table

Table 1 State Recycling and Waste Reduction Efforts.. .9 


\section{Preface and ACKNOWLedgments}

The concept for this report evolved from the work of the Environmental Partners' Project, whose members-legislators, legislative staff and representatives of the Foundation for State Legislatures-collaborated to produce several useful solid waste documents for the states. Their expertise and efforts were invaluable.

The authors would like to thank the United States Department of Energy (DOE) and the National Renewable Energy Laboratory (NREL) for funding a year-long project and making this publication possible; DOE's program manager, Simon Friedrich, and NREL's technical manager, Carlton Wiles, for their valuable review and oversight throughout the project; NCSL's Leann Stelzer for providing helpful comments throughout this process; NCSL's Linda Gaer for formatting the publication; and NCSL's Energy, Science and Natural Resources Program for providing continual support.

Special thanks are extended to the external reviewers of the report:

Roger Bernstein, Director of State Government Affairs, American Plastics Council Susan Cobb, Public Education and Program Development, Denver Recycles Luis Diaz, President, Cal Recovery Incorporated Marjorie A. Franklin, President, Franklin Associates, Ltd.

William E. Franklin, Chairman and Principal, Franklin Associates, Ltd.

Charlotte Frola, Project Officer, Solid Waste Association of North America

Sue Germanio, Legal Counsel to the Democratic Leader, Pennsylvania House of Representatives

Jonathan Greenberg, Director of Environmental Policy, Browning-Ferris Industries

David Lovell, Senior Analyst, Wisconsin Legislative Council Staff

Edgar M. Miller, Director of Policy and Programs, National Recycling Coalition

Representative Mary Mushinsky, Connecticut

Tom Osdoba, Research and Planning Coordinator, Minnesota Office of Environmental Assistance

Lisa Purtell, Manager, State Affairs, Steel Recycling Institute

Judy M. Sheahan, Director of Special Projects, The Municipal Waste Management Association

Joe Suchecki, Manager, Government Affairs, WMX Technologies

James L. Thompson, Program Manager, Georgia Environmental Facilities Authority

N.C. Vasuki, Chief Executive Officer, Delaware Solid Waste Authority

Kim Vollbrecht, Associate Director, State and Local Government Relations, Procter \& Gamble

The reviewers' constructive comments greatly improved the content of this report; however, responsibility for the final product rests with the authors. 


\section{EXECUTIVE SUMMARY}

The next decade will be pivotal for local, state and federal government management of municipal solid waste (MSW). Even though the 1980s fear of an MSW "crisis" seems to have faded, MSW management will continue to be a challenge-it cannot be tossed from policy agendas. Today, several other concerns remain about managing MSW. State legislators now are faced with MSW concerns such as increasing costs of solid waste programs, financing MSW infrastructure, technological advancements, flow control and a changing role in the partnership between federal, state and local governments and private industry to manage this resource.

Protection of public health and welfare through proper management of MSW from collection through final disposal is the responsibility of government. The two critical objectives are safe and cost-effective management of MSW. Traditionally, these objectives have been accomplished in a variety of ways, including public service ownership of facilities or contracts between units of government and private service providers, or some combination of these. Because of growth in private sector interest and capability in providing these MSW services, however, shifts are occurring in the specific means of meeting these public health and welfare needs.

State and local government budget pressures require that MSW management be as efficient and cost-effective as possible, while providing the greatest degree of public and environmental protection. Modern, integrated MSW management systems incorporate a combination of waste prevention, recycling, composting, energy recovery from waste combustion and landfilling. Unfortunately, in many areas of the United States the public still perceives MSW management to be a free service. States and local governments must work effectively together to counter this perception; full costs of MSW management must be made visible to the public either through user fees or by specific identification of these services in tax bills. States and local governments must cooperate to establish full cost accounting systems (also known as business-based accounting) so that MSW management costs can be effectively communicated to the public. Using effective accounting and cost analysis tools will allow MSW managers to more efficiently provide this public service.

Traditional costs of MSW management, however, are not the only consideration for integrated solid waste management (ISWM) planning. As with each management technique-waste prevention, recycling, composting, energy recovery from waste combustion and landfilling-other considerations need to be addressed when financing MSW management systems. Recycling, for example, has advanced from a geographically scattered, underfinanced condition to an attractive business opportunity. Although recycling programs have successfully achieved community support and high collection rates, some programs were losing money because of the lack of markets for the collected materials. This realization caused some waste authorities to modify their program

State and local
government
budget pressures
require that MSW
management be as
efficient and cost-
effective as
possible, while
providing the
greatest degree of
public and
environmental
protection.

State and local government budget pressures require that $\mathrm{MSW}$ management be as efficient and costeffective as possible, while providing the public and protection. 
States need to play an important role in the joint federal, state and local MSW management decisions. expectations. Because recycled goods could be returned to the market, some waste authorities assumed the programs could support themselves financially. However, recycling is a service much the same as any other disposal method. The benefits of keeping the waste from landfills could be considered a long-term cost saving mechanism of the MSW management program as a whole. Each waste management method has some costs involved with its use. Reflecting these costs in the price of delivering the services is important helping citizens understand the true costs of MSW management.

Technological advancements also make MSW management a dynamic issue for the states. For example, groundwater pollution from landfill runoff and leachates has been minimized by the use of liners, covers, leachate collection systems and monitoring systems. Often, these advancements precede public perception, and legislators are faced with combining the two. Making the public an active participant in MSW management planning decisions can accomplish this goal.

Many current MSW management concerns are transboundary issues-both within the state and across state lines. Increased costs, recycling and regionalization have altered the traditional view that a community can be self-sufficient in managing its solid wastes. This has led to concerns about interstate transport of waste and local government control over the waste flow.

Complicating a resolution of these issues are U.S. Supreme Court decisions ruling that waste services are protected by the Commerce Clause of the U.S. Constitution. As a result, state and local government controls placed on waste transport must not unduly restrict interstate commerce. Flow control, established through local ordinance, state statute or regulation requiring that waste be taken to designated facilities or restricting competition no longer is available to local governments as a waste management tool. States and local governments that are affected by flow control therefore are working to devise alternate management strategies.

Although the effect of these changes on capacity assurance planning and integrated waste management is unclear now one thing is certain; transboundary questions, including interstate waste and flow control, will remain overriding near-term topics in MSW management planning and policy development.

States need to play an important role in the joint federal, state and local MSW management decisions. Their role includes overseeing the implementation of federal landfill regulations, working with local or regional solid waste authorities to ensure that state MSW management goals are being met and planning for long-term waste management in a way that satisfies federal standards and local needs.

Overall, the future of MSW management depends on cooperative efforts among its stakeholders-local, state and federal governments, the private sector and the public. This collaboration will provide the necessary forum to reach long-term solutions to management needs. This guide incorporates a discussion of the MSW management issues described above with a comprehensive overview of the components of an ISWM system. Such discussion will allow individual state legislators to gain a better understanding of the MSW management issue, in general and examine how these concerns might apply to their particular state.

The guide complements other National Conference of State Legislatures (NCSL) efforts to address solid waste issues including publications compiled by the Environmental Partners' projects. They include: Guidelines to Evaluate State Solid Waste Management Policies and Programs; The Roles of Government, Industry and Consumers in Solid Waste Management; 
Environmental Considerations in Municipal Solid Waste Management Decisions; Solid Waste Management Goals; Recycling, Reduction and Diversion; Public Policy and Markets for Recycled Materials; and Packaging and Waste Management.

\section{About the NCSL Environmental Partners' Project}

In cooperation with NCSL's Foundation for State Legislatures, the NCSL Environmental Partners' Project was formed in 1994 to establish a forum for those with various roles in dealing with solid waste issues, but who rarely have an opportunity to work together. The partners include key state legislators, experienced state legislative staff and sponsors of NCSL's Foundation for State Legislatures who chose to participate in this project. The partners worked on several specific topics and have prepared six documents. The principal report, Guidelines to Evaluate State Solid Waste Management Policies and Programs, is designed to help states evaluate existing solid waste management policies and programs. The partners also have helped to draft a series of five concise issue papers that synthesize a range of topics. The topics include the roles of government, industry and consumers in solid waste management; environmental considerations in solid waste management; recycling; reduction and diversion goals; markets for recycled materials and packaging. 


\section{INTRODUCTION}

Trash. Garbage. Refuse. Rubbish. Municipal solid waste. No matter what it is called, its management cannot be tossed from state policy agendas. Because waste generation-209 million tons of municipal solid waste (MSW) generated in 1994 alone-and disposal are an implicit part of today's advanced lifestyle, it seems evident that MSW management planning no longer is an option, but a necessity.' Each state, therefore, must tailor on MSW management program to suit its specific needs.

In the past, some said that MSW was not a pressing issue because there seemed to be unlimited disposal capacity and no grave health or environmental problems were associated with disposal methods and sites. Many states therefore chose to deal with the MSW management issue in a reactive manner with moderate success. Since that time, some states have found it beneficial to address the concerns associated with MSW before they become "problems." Following the release of revised federal standards to regulate disposal facilities, states now find themselves in a cooperative MSW management relationship with federal and local governments.

This guide examines the nature and extent of solid waste issues, provides a history of some MSW issues, offers an overview of MSW management options, reviews federal efforts and discusses state and local MSW activities, planning and program implementation. This guide's discussion is limited to MSW. Because definitions of MSW vary, MSW is defined, for the purposes of this guide, as nonhazardous solid wastes from residential, commercial, institutional and limited industrial sources. MSW generally is composed of durable goods, nondurable goods, containers, packaging and other wastes such as yard trimmings and food. The discussion of MSW traditionally does not include medical wastes and hazardous material such as industrial chemical outputs. Materials such as construction and demolition debris (C\&D) can cloud MSW management considerations; therefore, C\&D is discussed within the "special wastes" section along with household hazardous waste, tires and white goods (large household appliances). 


\section{CurRent MUNicipal Solid WASTE MANAGEMENT ISSUES THAT AfFeCt StATES}

Municipal solid waste management is a business where government, service providers and consumers must work together to provide a safe environment.
Substantial changes have occured in municipal solid waste management over the years. A community no longer can simply dig a hole and bury trash. Management of MSW is more sophisticated. It is a business where government, service providers and consumers must work together to provide a safe environment.

Traditionally, local governments have directly provided MSW management services with state and federal support. Today, more locales are working with private industry to establish "public/private partnerships" to manage community MSW. Federal and state governments, in general, set standards, fund research and oversee operations of local government and the private sector. Local governments shoulder much of the direct responsibility for solid waste management services. Private industries collect, dispose of and recycle waste directly and reduce waste themselves through recycling and manufacturing products from recovered materials. Consumers, too, must take responsibility for managing waste and reducing the amount that is generated. By clearly assigning responsibility and commensurate authority for all phases of solid waste management, government, industry and consumers can be assured that solid waste is being managed properly.

To meet their management responsibilities, some states and locales are motivated to use flow control for a number of reasons: to require that waste generated within the borders of a local government be disposed at a designated facility; to have financial assurance that guarantee's the flow of materials to specific facilities and to meet waste reduction or recycling goals. States and localities that implement flow control measures, however, have come face-to-face with several legal questions under the Commerce Clause of the U.S. Constitution. Flow control captured national attention when the Supreme Court ruled against it in C\&A Carbone, Inc. vs. Town of Clarkstown, 114 Sup. Ct. 1677, 128 L. Ed. 2d 399 (1994). On May 16, 1994, the Supreme Court held that a local flow control ordinance was unconstitutional under the Commerce Clause. In the past, states and locales used flow control designed through state law, statute or city ordinance to direct MSW to facilities specifically approved for treatment or disposal.

The Carbone decision created a situation that may reverse the trend of controlling the flow of waste for financial assurance, and it is one of a series of Supreme Court rulings on solid waste since 1990. The latest rulings on flow control came from lower court decisions on two cases, USA Recycling vs. Town of Babylon 66 F. 3d 1272 and SCS Corporation vs. 
Smithtown 66 F. 3d. 502. The Supreme Court declined to review the Babylon case. In this case, the U.S. Court of Appeals for the Second Circuit held that a town may require by contract that trash be disposed at a designated facility. In the Smithtown case, the appeals court struck down the town's flow control ordinance, yet upheld the town's right to enter into contracts with waste haulers as a "market participant." Even though the long-term implications of these cases are unknown, the recent rulings seem to indicate that flow control may be an option for communities that are willing to participate with the same rights, risks and potential damages as others who take part in that marketplace.

States need to understand the complexities of MSW issues and realize that they may be faced with some difficult questions, such as:

- Can governments meet their MSW management responsibilities in light of the recent court decisions on flow control? If not, what do states do now? Have past situations foreclosed future options?

- How does the permitting of "mega" landfills affect these responsibilities and investments?

- What is the difference between public sector monopolies of these services and potential private sector monopolies? Should MSW management be considered a public utility service? Is the public interest served by either?

- Would reducing the role and responsibility of local governments for the sake of privatization create problems for the state?

- Should MSW programs be designed to make individuals more aware of their role in managing waste?

If they have not yet surfaced, it is feasible that these questions will in the near future find their way onto state and local MSW management program and policy agendas? By anticipating such questions, state and locales can develop comprehensive approaches to address these needs.

Additional MSW management topics this document discusses include: market volatility of recyclables, regionalization, privatization, flexibility in environmental protection standards, state and local government cooperation and public involvement.
States need to understand the complexities of MSW issues and realize that they may be faced with some difficult questions. 


\section{Nature AND EXTENT OF THE MUNICIPAL SOLID WASTE MANAGEMENT ISSUE}

The United States

has a legacy of more than 30,000 closed landfills that operated without the benefit of today's technology and management practices.
Modern integrated municipal solid waste management has evolved in response to changing concerns about health and the environment. For instance, in the 1960 s the nation focused attention on resolving water pollution problems. In the 1970 s we recognized the need to take care of air pollution problems. Subsequent pollutant removal from the air and water created new types of solid wastes. Improved capabilities for measuring contamination also helped point out the environmental problems created by open dumps for residential, commercial and industrial wastes. Groundwater and surface water pollution from landfill leachates as well as air pollution problems stemming from open burning of wastes, made relevant the intervention of local government into disposal methods. Concern about pollution, however, was not the only issue associated with waste management. Although recycling was prevalent through World War II, several events in the 1970s, including the Organization of Petroleum Exporting Countries (OPEC) oil embargo, reillustrated the need for wise management of resources and the need to conserve natural resources. As a result, communities began to examine individual components of the waste stream and found valuable, sustainable resources that could be reclaimed to extend disposal capacity, reduce energy consumption and conserve virgin materials-all characteristics of recycling. These issues provided the impetus for government involvement in waste disposal and the encouragement to increase recycling and waste-to-energy use. Federal intervention in pollution control resulted in raising the general standards for treatment and disposal of all types of wastes, including MSW. The enactment of the Resource Conservation Recovery Act (RCRA) in 1976 increased public awareness of solid and hazardous waste disposal problems.

Whereas pollution issues took priority in state policymaking because of the threat to human health, local governments began experimenting with recycling and waste-reduction programs. A cooperative effort between nonprofit groups and state and local governments during the 1970s and 1980s largely provided the basis for solid waste management until the mid-1980s. These groups helped to heighten awareness and encourage waste prevention and recycling to foster a sustainable environment.

Now, the United States has a legacy of more than 30,000 closed landfills that operated without the benefit of today's technology and management practices. For a variety of reasons, some of these closed landfills are on the federal national priority list—often referred to as the Superfund list-and others soon may be placed there. These sites exist in part because of the then limited understanding about the long-term implications of dumping. Before 1980, MSW and hazardous waste could be buried in the same landfills. 
Fear of a garbage crisis loomed over the nation nearly a decade ago. Changes in federal landfill requirements, closures of landfills and reports of dwindling disposal space helped to fuel this fear. Even though some years have passed and state and local governments are addressing these issues, some say the United States still faces a national solid waste crisis. This is only partially true. Today, a crisis occurs when a local or regional site is not available. This can be because of population density and growth, costs or socioeconomic and political considerations. Although landfill space is available at a price, landfills inevitably will reach capacity at some point: Landfills are designed to fill up and eventually close down. In many cases, however, capacity is ensured for a number of years because of the opening of a new, large landfill-often called a mega landfill-in combination with successful recycling and composting programs and waste-to-energy (WTE) use. Although states have the opportunity to site new disposal facilities, citizens' concerns about the environmental and health consequences of new facilities have kept many from being sited, especially in heavily populated areas. Furthermore, depending upon the location, it can be expensive to dispose of or landfill waste. If a site is outside the state or region, transportation costs and other expenses can increase. Therefore, many communities are encouraging further recycling and composting to help divert waste from disposal.

The federal government contributed to the urgency of state MSW management policy development with the passage in 1984 of the amendments to RCRA. These amendments directed the U.S. Environmental Protection Agency (EPA) to develop environmentally protective landfill standards intended to prevent landfills from contaminating groundwater or causing other health or environmental problems. These RCRA regulations, within Subtitle D, require composite liners, leachate collection systems, methane and groundwater monitoring, closure, post-closure monitoring and financial assurance. Subtitle D regulations have contributed to the closure of several landfills and have convinced states of the need for long-term MSW management planning. Because adequate short-term disposal capacity needs have already been addressed by the states, today's efforts should focus on costeffective programs to achieve reduction, proper management, transport and disposal of waste and increased recycling.

Many states have shifted their policy focus toward an integrated MSW management approach, instead of relying on a single method such as landfilling. Integrated solid waste management (ISWM) tries to divert goods from land disposal through recycling, composting and combustion and strives to reduce the solid waste stream as a whole through source reduction. By developing an ISWM plan, states and local governments are able to select appropriate management methods to suit their needs and allow them to comprehensively address MSW management over the longterm. Today, communities strive to use integrated MSW programs. This signals a shift in management from a focus on disposal to an emphasis on resource conservation.
Many states have shifted their policy focus toward an integrated MSW management approach, instead of relying on a single method. 


\section{INTEGRATED MUNICIPAL SOLID WASTE MANAGEMENT}

\section{States and municipalities must understand the characteristics of their own waste stream and manage it in the most efficient manner possible.}

The MSW stream is characterized by the types and quantities of material generated, the number of materials processed or recovered through various means such as recycling and the amount not created in the first place as a result of waste prevention efforts. The material that is diverted from the waste stream through waste prevention is more difficult to pinpoint and generally is accounted for by examining the predicted amount of waste generated on a per capita calculation rather than the actual amount generated. For example, although few landfills weighed or measured solid wastes at the time, EPA predicted in 1975 that 225 million tons_or 5 pounds of garbage per person per day-would be generated in 1990 . Even though MSW generation varies greatly from place to place, by 1994, the predicted figure of waste generated was closer to 4.4 pounds per person per day, or 207 million tons. ${ }^{2}$ The decrease from the original estimate may be attributed to many factors, including better, more sophisticated data bases for calculating such figures, an economic recession, source reduction, lighter-weight packaging and changes in the manufacturing process. Today, predictions and estimates are the only method used to perform national waste calculations, because a national data base that includes actual measurement of waste does not exist. Because, all new landfills and energy recovery plants now have weigh scales, however, a relatively reliable national data base might be developed in cooperation with the states. Such a system eventually could displace the current reliance on an input-output model for estimates.

Consumer pressure and an incentive to reduce manufacturing and production costs are the primary reasons that waste prevention occurs. Technology and manufacturers' use of innovative methods to prevent waste certainly spurs these efforts. Other important contributions to minimizing the waste stream include materials substitution-plastic for glass-lightweighting of packaging, source-separated composting and changes in yard trimming management to include backyard composting, use of mulching mowers and banning yard trimmings from landfills. EPA predicts the per capita generation rate will remain constant at 4.4 pounds by 2000 . These waste generation figures are calculated based on shifts in federal and state policy decisions and should be used only as background information. States and municipalities must understand the characteristics of their own waste stream and manage it in the most efficient manner possible. As part of this process, it is necessary to examine the characteristics or types of MSW in the entire waste stream.

\section{Solid Waste Characteristics}

The municipal solid waste stream can be categorized into five areas: durable goods, nondurable goods, containers and packaging, yard trimmings and other wastes. Figure 1 
illustrates the Franklin Associates' inputoutput model of estimating waste generation in the United States. Because state solid waste characterization may vary from the national average, states should use caution in comparing data.

In general, durable goods are defined as those with a life span of more than three years. This category includes items such as household appliances often called "white goods," furnishings, consumer electronics and automobiles. MSW managers frequently label these items as "oversized and bulky" and deal with them differently than the other materials in the waste stream. Because of unique disposal requirements by state governments, some durable goods like large household appliances may not be mixed with the rest of the materials at the landfill or combustion facility and often are picked up separately from the rest of the waste stream. Smaller appliances, electronics, computers and furniture are durable goods that can be collected with household MSW and, in many cases, can be disposed of in landfills and combustion facilities.

\section{Figure 1. Products Generated in MSW, by Weight, 1994} (Total Weight $=209.1$ million tons)

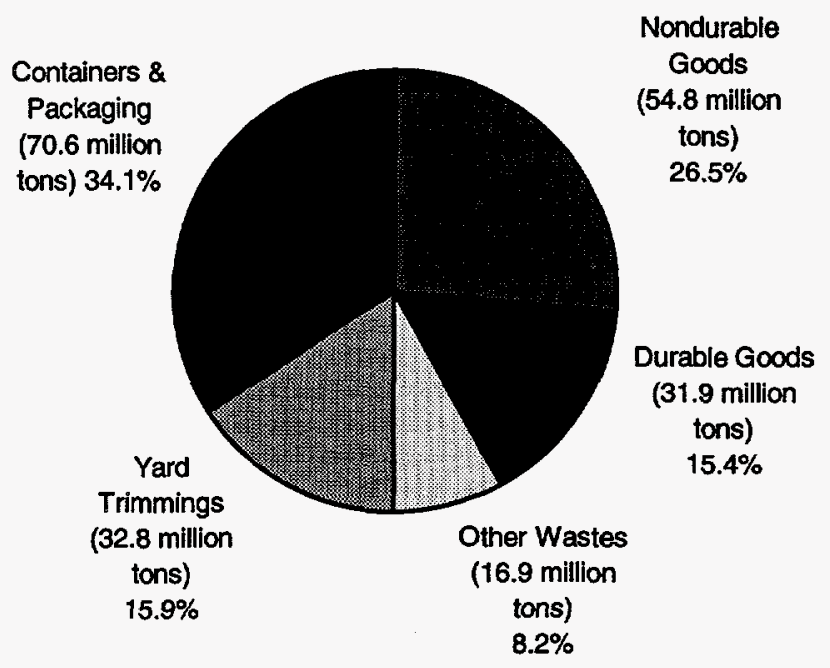

Source: Environmental Protection Agency, "Characterization of Municipal Solid Waste in the United States: 1995 Update."

Nondurable goods are defined as those with a useful life span of three years or less. The majority of these goods are discarded the same year they are manufactured. Paper products account for a large portion of nondurables and plastics and textiles account for the remainder.

The container and packaging category includes primary, secondary and tertiary packaging. Primary packaging is the container or packaging that directly holds the product (food, beverage, toiletries etc.) and can include tamper-proof closures. Secondary packaging is outer wraps, boxes or bundles. Tertiary packaging typically includes corrugated boxes, plastic overwrap and wood and plastic pallets. This packaging is used to ship the product, to prevent theft and some tampering or for advertising purposes. It is assumed that all containers and packaging are discarded within the year they are manufactured. Paper and paperboard-like corrugated boxes_account for most of the material in this category.

Besides yard trimmings, the remaining material in the waste stream is categorized as "other wastes." Items in this category include food wastes and assorted inorganic wastes that have varied life spans. Construction and demolition (C\&D) debris typically is not included in the national figures for waste generation; some states, however, include C\&D wastes in their calculations. 


\section{Management Approaches}

After several decades of reactive response to MSW management concerns and problems, federal, state and local governments, as well as the private sector and individual consumers, have realized the importance of working together to examine the situation and develop long-range plans to manage MSW. Each state has at least minimally addressed solid waste issues by adopting the requirements of the federal Subtitle D MSW landfill standards or by adopting more stringent requirements. Most states have received, or are about to receive, the statutorily required EPA approval of their Subtitle D MSW landfill programs. Besides developing disposal regulations, several states have focused on specific MSW issues or have tried to take a comprehensive approach to MSW management.

For many, an integrated approach is used to address the multiplicity of concerns surrounding comprehensive MSW management. Integrated solid waste management refers to the complementary use of a variety of waste management processes to safely, economically and effectively handle the MSW stream with the least adverse effect on health and the environment. Such an approach allows individual states and locales the flexibility to tailor their MSW management programs to meet specific needs. An ISWM system incorporates most or all of the following: waste prevention, recycling, composting, waste combustion to reduce volume (with energy recovery) and landfilling. Each system must be integrated, that is properly

\section{Figure 2. Percentage of Waste Managed, by Method}

Total Solid Waste $($ tons/yr.) $=209.1$ Million

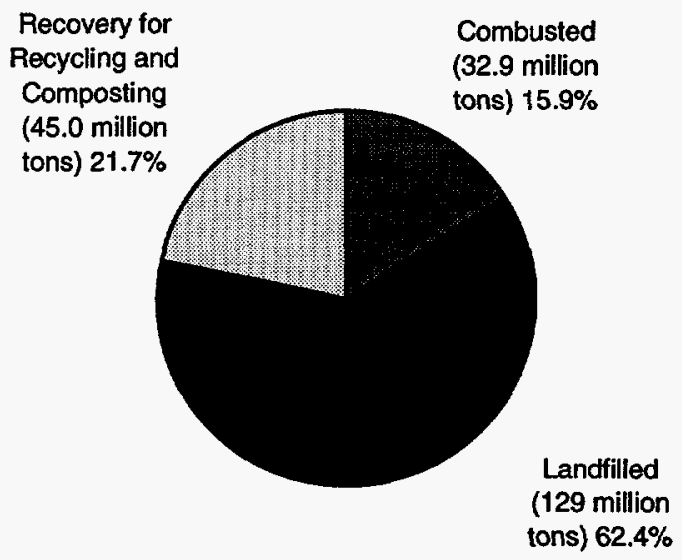

Source: EPA, "Characterization of Municipal Solid Waste in the United States: 1994 Update." designed to fit the other. These processes must be complemented by effec-tive storage, collection and transfer systems. This differs from EPA's discussed hierarchical approach for MSW man-agement. Even though EPA never required or encouraged the use of the hierarchy in literal terms, over time many have interpreted it with strict adherence that requires states to exhaust each element of waste management before moving to the next. Some states embrace such a preferential ranking options/alternatives, where they must, for example, reduce as much as possible, recycle as much as possible, then move on to combustion and landfilling. Most, however, do not require strict adherence and, instead, offer a range of options to manage waste, thereby allowing communities to tailor a waste management program to meet their needs.

As a state examines its solid waste needs, each MSW management approach may be considered to determine the one best suited to meet the state's long-term objectives. Since 
As a state examines its solid waste needs, each MSW management approach may be considered to determine the one best suited to meet the state's long-term objectives. Since

\section{Table 1. State Recycling and Waste Reduction Efforts}

\begin{tabular}{|c|c|c|c|c|c|}
\hline (7) & 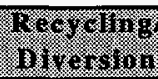 & r. & 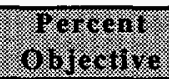 & 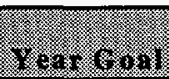 & 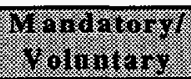 \\
\hline $\begin{array}{l}\text { Alabama } \\
\text { Alaska }\end{array}$ & $\sqrt{ }$ & & $25 \%$ & & $V *$ \\
\hline Arizona & & & & & $\mathrm{V} * *$ \\
\hline Arkansas & $\sqrt{ }$ & & $40 \%$ & 2000 & $\mathrm{~V} * *$ \\
\hline California & $\sqrt{ }$ & & $50 \%$ & 2000 & $\mathbf{V *}$ \\
\hline Colorado & $\sqrt{ }$ & & $50 \%$ & 2000 & V \\
\hline Connecticut & $\sqrt{ }$ & & $40 \%$ & 2000 & $\mathbf{M}$ \\
\hline Delaware & $\sqrt{ }$ & & $21 \%$ & 2000 & $\mathrm{~V} * *$ \\
\hline District of Columbia & $\checkmark$ & & $45 \%$ & 1995 & $\underset{\mathrm{V} * *}{\mathbf{M}}$ \\
\hline Georgia & & $\sqrt{ }$ & $\begin{array}{l}30 \% \\
25 \%\end{array}$ & $\begin{array}{l}1990 \\
1998\end{array}$ & $\mathrm{~V} * * / * *$ \\
\hline Hawaii & $\checkmark$ & & $50 \%$ & 2000 & $V^{*}$ \\
\hline Idaho & $\sqrt{ }$ & & $25 \%$ & 1995 & V \\
\hline Illinois & $\sqrt{ }$ & & $25 \%$ & 2000 & V* \\
\hline Indiana & & $\sqrt{ }$ & $50 \%$ & 2000 & $V *$ \\
\hline Iowa & & $\sqrt{ }$ & $50 \%$ & 2000 & $\mathrm{~V} *$ \\
\hline $\begin{array}{l}\text { Kansas } \\
\text { Kentucky }\end{array}$ & & $\sqrt{ }$ & $25 \%$ & 1097 & $\mathrm{~V} *$ \\
\hline Louisiana & $\sqrt{ }$ & & $25 \%$ & 1992 & V \\
\hline Maine & $\sqrt{ }$ & & $50 \%$ & 1998 & $\mathrm{~V} * * *$ \\
\hline M aryland & $\sqrt{ }$ & & $20 \%$ & 1994 & $\mathrm{~V} *$ \\
\hline Massachusetts & $\sqrt{ }$ & & $46 \%$ & 2000 & $V^{*}$ \\
\hline Michigan & $\sqrt{ }$ & & $50 \%$ & 2005 & $V^{*}$ \\
\hline Minnesota & $\sqrt{ }$ & & $35 \%-50 \%$ & 1996 & $V^{* *} *$ \\
\hline$M$ ississippi & & $v$ & $25 \%$ & 1996 & V \\
\hline Missouri & & $\sqrt{ }$ & $40 \%$ & 1998 & $V^{*}$ \\
\hline Montana & & $\sqrt{ }$ & $25 \%$ & 1996 & V \\
\hline Nebraska & & $\sqrt{ }$ & $50 \%$ & 2002 & V \\
\hline Nevada & $\sqrt{ }$ & & $25 \%$ & 1994 & $\mathrm{~V} * / * *$ \\
\hline New Hampshire & & $\sqrt{ }$ & $40 \%$ & 2000 & $V^{*}$ \\
\hline New Jersey & $\sqrt{ }$ & & $60 \%$ & 1995 & $\mathbf{M}$ \\
\hline New Mexico & $\sqrt{ }$ & & $50 \%$ & 2000 & $V^{*}$ \\
\hline New York & $\sqrt{ }$ & & $50 \%$ & 2000 & $\mathbf{M}$ \\
\hline North Carolina & & $\sqrt{ }$ & $40 \%$ & 2001 & $\mathrm{~V} * *$ \\
\hline North Dakota & & $\sqrt{ }$ & $40 \%$ & 2000 & V \\
\hline Ohio & $\sqrt{ }$ & & $25 \%-50 \%$ & 2000 & $\mathrm{~V} *$ \\
\hline Oklahoma & & & & & \\
\hline Oregon & $\sqrt{ }$ & & $50 \%$ & 2000 & $\mathrm{~V} * *$ \\
\hline Pennsylvania & $\sqrt{ }$ & & $25 \%$ & 1997 & $\mathbf{M}$ \\
\hline Rhode Island & $\sqrt{ }$ & & $70 \%$ & & $\mathbf{M}$ \\
\hline South Carolina & $\sqrt{ }$ & & $30 \%$ & 1997 & $\mathrm{~V} * *$ \\
\hline South Dakota & & $\sqrt{ }$ & $50 \%$ & 2001 & $V *$ \\
\hline Tennessee & & $\sqrt{ }$ & $25 \%$ & 1996 & $\mathrm{~V} *$ \\
\hline Texas & & $\sqrt{ }$ & $40 \%$ & 1994 & $V^{*}$ \\
\hline Uan & $a^{2}$ & & $10 \%$ & 2000 & $\mathbf{V *}$ \\
\hline vimont & 4 & & $250 \%$ & 2000 & * \\
\hline w ashington & $y$ & & $50 \%$ & 1005 & $v * *$ \\
\hline W est Virginia & & & $50 \%$ & 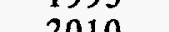 & $M / V$ \\
\hline$W$ isconsin & & & & & IVI/ \\
\hline $\min$ & & & & & \\
\hline
\end{tabular}

* Local governments/solid waste authorities required to develop recycling plans

** Local governments/solid waste authorities required to provide opportunity to recycle

*** Source separation required for businesses

*/**Recycling plans requíred of rural local governments; opportunity to recycle required of urban local governments

*****Local governments/solid waste authorities required to plan 
It is not enough simply to set state goals for waste reduction, diversion or recycling. Several other factors influence the development of MSW management plans and programs. no management method is without environmental effects, states must examine their unique needs and choose components of an integrated management approach to meet those needs. The five approaches to consider when developing an integrated MSW management plan include: waste reduction (and prevention), recycling and reuse, composting, energy recovery from waste combustion and landfilling. Of the total MSW generated in the United States in 1994, approximately 23.6 percent was recycled or composted, 15.5 percent was combusted and 60.9 percent was landfilled. ${ }^{3}$. Waste reduction is difficult to measure because it involves not generating waste in the first place. Therefore, figures arenot readily available. Caution should be exercised when evaluating these and other data. Be sure to understand what information is illustrated. For example, note that figure 2 does not differentiate between recycling and composting. Sometimes yard waste or its composted end product is diverted to a landfill for disposal. In this case, it should not be counted as recycled. Some argue, however, that if the compost end product is used as daily landfill cover it may be counted in the recycling percentage.

Although ISWM has not been adopted_uniformly across the country, 41 states, including the District of Columbia, have some type of comprehensive recycling or waste reduction laws with components of the integrated approach. As illustrated in table 1, 44 states chose to legislate or announce goals for recycling, waste reduction or waste diversion, thus redirecting resources away from land disposal. Such goals range from Maryland's 20 percent recycling rate to Rhode Island's 70 percent. These goals generally are used to track a state's progress and define successful MSW management. Comparison of success rates among the states is difficult, however, due to the different materials included in the calculations and the different methodologies used to determine achievement of specific state goals. EPA is currently trying to develop a uniform methodology to help states measure their future waste reduction and recycling rates.

In the meantime, as states track their own progress, 20 report their recycling rate at or surpassing 25 percent in 1995 . Three of those states report a rate above 40 percent, and nine report a rate at or above 30 percent. Averaging all the reported recycling rates results in a national recycling rate of 27 percent. ${ }^{4}$ Although some critics say that it can be counterproductive to compare states' declared successes or focus too much attention on rates, these calculations often help states gauge their progress and encourage their citizens to continue supporting recycling and waste reduction.

State recycling and waste prevention goals fall into two categories-voluntary and mandatory. Voluntary MSW reduction, recycling or diversion goals usually are set by state government to encourage comprehensive MSW management within local or regional solid waste authorities. States with voluntary goals often provide technical assistance or grants to help locales establish recycling and waste reduction programs. Mandatory waste reduction and recycling goals usually must be achieved by a statutorily set deadline. States have found that recycling goals are more difficult to meet than anticipated. Many goals were purposely set to be aggressive and reflect a series of policy choices based upon limited and experience. Other factors-such as high costs from poorly implemented programs or programs that try to meet extremely aggressive goals-suffer from the law of diminishing returns. Population growth and swings in recycled materials markets also may cause problems. Better program implementation and evaluation of approaches that would help goals become achievable are constantly being reviewed. Many states, therefore, are shifting from mandatory requirements to voluntary initiatives.

It is not enough simply to set state goals for waste reduction, diversion or recycling. Several other factors influence the development of MSW management plans and programs. States need to examine collection and transportation issues associated with each management 
approach (except waste reduction). For each facet of a state's integrated waste management approach, several concerns need to be addressed, including:

- Who will be responsible for the program's implementation and the collection of materials?

- Will the services be carried out by a public agency or through a private contractor?

- Where are the markets for the collected materials?

- How will the materials be transported to the markets?

If, for example, transportation and collection issues are not addressed from the outset, they can hinder the successful implementation of any MSW management approach. State and local government officials also should consider environmental and economic trade-offs when selecting waste management and recycling options.

Waste prevention. Waste prevention is the most fundamental means of decreasing the actual volume of waste disposed. If waste is not generated, disposal is unnecessary. Waste prevention results from changing the processes and practices that generate waste. Waste prevention generally can be divided into three categories:

- Making products with less material. Often called "lightweighting," this process usually is accomplished by reducing the amount of packaging used to ship and protect products. Use of such innovative techniques and product reformulation also are important contributors to waste prevention. Glass and steel shared the container needs of the beverage industry, for example, until the beverage industry searched for a better container and developed the aluminum can. Because the consumers liked the aluminum can, it consequently took the largest market share. Aluminum can manufacturers embarked upon "lightweighting" to reduce can prices. Steel can manufacturers have been forced by the intense competition to reduce container weight. Marketplace competition plays a significant role in preventing waste. Making products using fewer raw materials and less energy has been the mainstay of the United States vindustry because the marketplace consistently rewards the lower-cost supplier.

- Reducing toxicity of a package or product. With passage of the Coalition of Northeastern Governors' (CONEG) Model Toxics Reduction Act in 1990, Maine became the first state to require the reduction of certain types of toxics-cadmium, lead, mercury and hexavalent chromium-in packaging. Since that time, 17 other states have followed suit (Connecticut, Florida, Georgia, Illinois, lowa, Maryland, Minnesota, Missouri, New Hampshire, New Jersey, New York, Pennsylvania, Rhode Island, Vermont, Virginia, Washington and Wisconsin). ${ }^{5}$ The toxics reduction legislation enacted by the 18 states becomes national in scope, given the distribution infrastructure, because it usually is very difficult (and cost-prohibitive) to make products one way for some states and another way for others.

- Waste prevention through consumer activities. Although this is the most difficult process to measure, it eventually may be the most effective. Consumer waste prevention requires people to exercise their purchasing power by purchasing products with less packaging, buying in bulk and using reusable products and containers. Other consumer activities include backyard composting (on-site treatment), making doublesided copies, and so on.

By not creating waste in the first place, the real power of waste reduction lies in the savings. Savings can be acheived both in the manufacturing (mostly through energy reduction) and
Waste prevention is the most fundamental means of decreasing the actual volume of waste disposed. 
Recycling can be an effective way to preserve disposal capacities and thereby increase the sustainability of resources. disposal (collection, hauling, landfill fees and space) processes. Using variable rate pricing for collection, where charges are based on the amount of waste set out for disposal, encourages citizens to reduce waste or recycle to save money. Aggressive education campaigns can help communities transition to this method of disposal. Waste prevention also softens the demand for mining and timbering, which thereby reduces the damage and ecological effects of those activities and increases sustainability.

Recycling. Recycling combined with landfilling or waste combustion combined with energy recovery is practiced by many communities throughout the United States. Recycling has gained widespread acceptance and popularity because it can divert some materials from disposal, thereby saving landfill space. Recycling provides a means to recover valuable materials and helps to achieve environmental sustainability by conserving resources. Through recycling citizens often feel part of a successful MSW management program.

The national recycling rate reached 27 percent in 1995, compared with 23 percent in $1994 .^{6}$ These figures include traditional materials separation programs for newspaper, glass, aluminum, steel and several types of plastic containers. They also include calculations for yard waste diversion. Regions with more yard debris may appear to have higher recycling rates. Curbside recycling services also were provided in 1995 to more than 121 million people, or 46 percent of U.S. households.

sustainability of resources. As with all management options, however, states need to examine the environmental implications, the markets for the collected materials, the program costs and the transportation and collection issues that are inherent in this management method. Some argue that it does not make sense to expend more resources to recycle a material than it takes to produce that material and dispose of it in another way. Others argue that recycling always must be exercised. The resources saved by not using virgin commodities may outweigh the costs of using recycled materials. In the future, the costs of recycled materials may decrease enough to equalize these external costs. Financing ISWM is discussed in more depth in the financing and revenues section of the state and local government section.

In recent years, state policies have begun to shift toward market development that creates a demand for products, rather than relying strictly on supply-side tools (e.g., simply collecting materials). Policies such as procurement programs that include "buy recycled" campaigns, price preferences for recycled content goods and mandatory recycled content for newsprint helped to boost the recycled materials market from a record low in 1993 to a record high in 1995. Because the market is in a continuous state of flux-that is the nature of a free market system-states should consider stimulating both supply and demand without placing too much reliance on either. State support of recycling programs alone, however, cannot ensure robust market conditions.

The availability of markets for recycled materials affects the types of materials that an MSW program collects. Local recycled material markets can be encouraged through state procurement programs. Such programs can be mutually beneficial and have a significant effect on the amount of recycled goods purchased. Often states will make their recycled content bid prices available to local governments to take advantage of bulk purchasing. Secondary material markets also are influenced by international markets and events. If the nearest facility for processing a certain recovered material is outside the state (or even outside the region), it may be more costly both fiscally and environmentally for the state or its solid waste authorities to separately collect and transport the recycled material than it would be to use other MSW management options. Local governments understand that the distance to markets, associated transportation costs and public support will affect recycling 
program costs and decisions. Strong public support for recycling will require local governments to integrate recycling and system redesign so they can take advantage of the cost savings that result from recycling and other efficiency measures. As with all MSW management options, the local or regional waste management authority must communicate such issues to the public so it can develop the most sensible approach.

Composting. Composting is in vogue because it can divert a large amount of organic material, including yard trimmings and some food wastes, from landfilling and, in some cases, from waste collection. Composting is a way to accelerate and control the naturally occurring biodegradation of organic material into a soil-like substance. It has been modified for human use to include the treatment of portions of the organic fraction of MSW and other wastes. Composting can be divided into two broad categories: aerobic and anaerobic.

- Aerobic composting occurs by the activity of microorangisms that require oxygen. The aerobic process involves collecting the waste, forming it into long rows (known as windrows) or static piles and adding air, either by turning these rows or piles or forcing air through the pile or mass. Several factors must be properly controlled (moisture, temperature, carbon-to-nitrogen ratio and others) if the composting process is to be completed satisfactorily. Compared to anaerobic composting, aerobic composting proceeds rather quickly and does not result in excessively unpleasant odors. Temperatures also are higher and, when properly controlled, the process yields a product that is essentially free of harmful pathogens and weed seeds.

- Anaerobic composting is the degradation of the organic materials by microorganisms that do not require oxygen. It is characterized by longer composting times, lower temperatures and excessive foul odors. Because of these and other factors, anaerobic composting is not widely practiced.

Although similar to anaerobic composting, anaerobic digestion is conducted in an enclosed environment and relies on a number of different microorganisms to convert the organic materials to biogas and a compost material. The biogas (methane) is recovered and can be used as an energy source. The compost product also can be recovered and used. By operating in controlled temperature ranges in a waste treatment process, the rate of anaerobic digestion is significantly increased compared to the naturally occurring process. For high solids feedstocks such as MSW, the temperature can be further increased.

Most MSW composting is source separated-organic materials such as food scraps and yard trimmings are extracted from the waste stream-for collection or backyard composting. Some communities, however, have introduced mixed MSW composting into their management plans. Mixed MSW composting usually means that paper products and, perhaps, shredded wood are composted along with yard trimmings and food wastes. Other organic materials such as textiles and rubber are not readily composted. Inorganic materials such as metals and glass cannot be composted, neither can plastics, which are classified as organics. Some recycling advocates feel that mixed waste composting diverts viable inorganic material from the more productive recycling loop. The final product of such mixed MSW composting is used for a variety of applications such as surface mine reclamation and landfill cover.

According to 1995 estimates, these organic wastes comprise approximately 26 percent of the MSW stream. ${ }^{8}$ Although several states have enacted disposal bans on yard trimmingsone type of organic material-most states rely on local or regional MSW authorities to implement composting programs. Many cities find that focusing diversion on a substantial percentage of the waste stream offers them the most successful return. A program with
Composting is a way to accelerate and control the naturally occurring biodegradation of organic material into a soil-like substance. 
Community

education

programs can help

to ensure that

composting is

successful. separate collection of yard wastes may be economically justified, however, only if such materials actually are composted and used. Some communities operate separate, centralized composting facilities in conjunction with the solid waste authority. Many of these facilities accept organic material such as yard trimmings and food scraps from a variety of sources and process the waste on a large scale.

Backyard composting programs provide an opportunity for citizens to remove some of their organic wastes from the disposal stream. Citizens who compost their yard wastes and some food scraps at home help their community avoid the environmental and economic costs of collecting, transporting and landfilling these recyclable wastes. Community education programs can help to ensure that backyard composting is succesful. Another popular form of diverting yard trimmings from the MSW stream that is often overlooked is the use of mulching lawn mowers. When the clippings are left on the ground, grass is diverted from the waste stream and the cost associated with a composting facility is avoided or minimized.

Composting is not without its problems, however. Noncompostable materials in the MSW can contaminate the final organic compost product, thus limiting its quality and usefulness. Therefore, some states have composting guidelines to ensure the quality of the final end product. Depending upon the intented use of the product, additional processing may be required. If more processing is required to prepare the product for use or markets, more expense is involved. Questions also have been raised about odor, leachate runoff, vermin, economic viability and potential health problems associated with composting facilities. Although some facilities have been closed because of foul odors, most of these problems can be solved with sound management practices. These same concerns also are raised in discussions about landfills and recycling facilities.

Most states that have chosen to promote backyard composting have done so because it is an inexpensive option that does not require a sophisticated change in agency infrastructure. Although centralized composting facilities offer the most control over the process, state governments that encourage the use of such facilities should be aware of the capital, transportation and other costs associated with establishing and operating the facility. States also need to encourage the purchase of, and promote the benefits of, the facility's endproducts. Even though the amount of organic waste varies by season and geographic location, composting programs can significantly help states meet waste diversion goals.

Energy recovery from waste combustion. For centuries, the burning of solid waste was a common method of disposal. It was not until the 1970 s that open burning was widely prohibited in the United States because of concern about air pollution. Since then, increasingly stringent environmental controls have been mandated, and combustion facilities built today must meet strict federal and state air pollution requirements. Municipal waste combustion (MWC) can be used to reduce the volume of the solid waste stream that ultimately must be landfilled by up to 90 percent, thus extending disposal capacity. Most modern MWC facilities-called waste-to-energy (WTE) facilities-burn solid waste to generate electricity or steam and sell it as an alternative energy source. It is estimated in fact, that WTE facilities could supply up to 2 percent of the electrical power needed in the United States. ${ }^{9}$ The two main types of WTE facilities are:

- Mass-burn facilities that burn MSW as it is delivered to them, without any preprocessing. - Refuse derived-fuel (RDF) plants that remove recyclable materials and noncombustibles, then shred or process the combustible fraction of the waste stream into a relatively uniform solid fuel. In 1995, 121 WTE facilities and 27 facilities without energy recovery burned more than 100,000 tons of waste daily. 
Other countries-most notably Germany, the Netherlands, Sweden, Switzerland, Denmark, Austria, France and Japan-are relying on greater use of WTE facilities for volume reduction and energy recovery. Germany, for example, has set 2005 as the deadline to prohibit landfilling of wastes that contain more than 5 percent carbon. The Netherlands currently bans the landfilling of combustibles, cardboard and paper; direct landfilling of other components will be banned in 2000 . These nations, our direct competitors in the world economy, benefit from recovering energy from nonrecyclable but combustible solid wastes, protect surface and groundwater resources in the long-term (by elimination of post-closure care of landfills), decrease long-term liability costs, reduce fossil fuel use and conserve land.

Although MWC may seem a logical step for any integrated MSW plan, its by products - air emissions and ash residue-are the basis for controversy. Currently, some of the more disputed air emissions are volatile metals (e.g., mercury) and the chemicals tetrapolychlorodibenzo-p-dioxin and polychlorodibenzo furans, commonly referred to as "dioxin." Various organizations and government agencies continue to debate the sources of dioxin and its health and environmental impacts. Therefore, EPA is planning a three-year study to identify all sources of dioxin.

MWCs are tightly regulated by rules promulgated under the authority of section 111 of the Clean Air Act. EPA Administrator Browner signed final Emission Guidelines and New Source Performance Standards for MWCs on Oct. 31, 1995. These rules require most existing MWCs to install additional air pollution control equipment to meet stringent emission limitations. One effect of these "MACT" (maximum achievable control technology) standards will be to reduce emissions of dioxin from MWCs by approximately 99 percent by 2000 . According to EPA, MWCs then will account for less than 1 percent of all known or suspected dioxin sources.

Controversy existed for several years about ash generated from MWC. This controversy was primarily over whether the ash was exempt from RCRA Subtitle C (i.e., hazardous waste) regulations. The question eventually was decided by the Supreme Court on May 2, 1994, in a case between the Environmental Defense Fund and the City of Chicago. The court ruled that the ash was not exempt from the hazardous waste regulations. The result of the ruling was that the owner/operator and generator of the ash had to make a "determination" as to whether the ash was a hazardous waste. When they choose to test their ash, most facilites use EPA's toxicity characteristics leaching procedure (TCLP). The results of the TCLP determine whether the ash is hazardous. Before the ruling, many states had required that waste-to-energy facilities test their ash. Many other states and combustion facility operators voluntarily accepted this responsibility. Since the ruling, most facilities test their ash and have routinely found their ash to be nonhazardous. Following the ruling, EPA issued guidance for sampling and analysis of the ash, which permits the industry to test the ash as it exits the facility. These actions ended a long period of uncertainty for the waste-toenergy industry.

After the Supreme Court ruling, virtually all MWC facilities tested their ash using the EPA protocols. Some facility operators installed processes to treat ash. Ash characterized as "nonhazardous" can be disposed of in a typical MSW landfill or an ash monofill. Leachate from ash monofills has consistently been below ground water standards for metals and often close to drinking water standards. In addition, ash can be used as landfill cover and in various construction products (i.e., asphalt, cement, road bed aggregate etc.), where acceptable. EPA and others have conducted studies on the land disposal and beneficial use of ash from municipal waste-to-energy facilities and have found no evidence to suggest that ash disposal in a municipal solid waste landfill that complies with regulations will endanger human health and the environment. Countries such as Japan, Denmark, the Netherlands and Germany allow use of municipal waste combustion ash in construction projects.
It is important for a legislator to obtain a wide variety of information about MSW management options when developing a state MSW management plan. 


Landfilling waste
has been a
disposal practice
for years and
continues to be an
essential part of
any integrated
approach to MSW
management.

Landfilling waste disposal practice for years and continues to be an essential part of any integrated management.
As with the siting of other types of MSW facilities, political, technical and financial considerations must be taken into account in an assessment of MWC. Evaluating program and capital costs, transportation issues and environmental impacts inherent in the MWC process is necessary. Concerns about emissions, ash and some negative public perceptions may intensify this debate. MWC and recycling programs can complement one another, as demonstrated by the high levels of recycling achieved in communities with MWCs. Yet, communities need to pay special attention to the potential for competition between MWC and recycling. One benefit that MWCs can offer a community are materials whose market demands fluctuate. For example, when the market price for plastics reaches zero or negative numbers, it may be more beneficial to recover energy from the plastics than to landfill them. Because MWC facilities can have high capital and initial operating expenses, state and local governments need to be aware that such costs may encourage the use of public/private partnerships, yet raise questions about a facility's long-term costeffectiveness. It is helpful therefore for a legislator to obtain a wide variety of information about MSW management options when developing a state MSW management plan.

Sanitary landfilling. Landfilling waste has been a disposal practice for years and continues to be an essential part of any integrated approach to MSW management. As states recognize that landfills are a necessary component of MSW management, they can begin to decide how landfills might best be used. Disposing waste in sanitary landfills may be attractive to states with available land, and it can be financially flexible. Landfills are ongoing construction projects that are not completed until they are filled; therefore, capital expenses for the facility are accrued over time. States with limited available land may elect to exhaust other management approaches first or export their waste to a more distant location.

Modern landfill practices have considerably decreased the pollution problems associated with the nation's previous open dumps. Although open dumps were not protective of the environment and sometimes released contamination into groundwater and surface supplies, current standards for disposal of MSW on land prohibit the acceptance of most hazardous materials. A few states have banned materials such as waste oil that typically are accepted in Subtitle D landfills. Sanitary landfills must be equipped with composite liners or leachate detection, collection and removal systems to protect groundwater from leachate and must apply cover daily to control vectors and litter, minimize fires and provide a more aesthetic appearance. After the landfill is filled with solid waste it is capped with a clay or synthetic cover and layers of topsoil. The cap minimizes rainwater intrusion, thus decreasing the quantities of leachate that would be generated. Because no landfill liners will ensure 100 percent control of leachate, landfill operators must provide post-closure assurance protection for 30 years from groundwater contamination, landfill gas migration and cover integrity and other such problems, in accordance with RCRA Subtitle D regulations. These regulations contain other landfill criteria, including requirements for siting, operation, design, corrective action and financial assurance. These criteria must be met by both public and private landfill operators. Following the minimum 30-year requirement for postclosure care assurance, state governments will become responsible for any problem that arises after the owner transfers the site to the local government. This is an important point for states to realize. The long-term liability for closed landfills is unknown.

Municipal solid waste landfills generally have been designed and operated to keep out moisture, prevent run-on and run-off of water and to collect and treat the leachate. This strategy, which is required by Subtitle $D$ regulations, keeps the landfill relatively dry, thus impeding the degradation of the waste deposited in the landfill. Within the technical community, some scientists believe this approach is incorrect and that it should be modified to permit the recirculation of leachate or the addition of moisture and, perhaps, nutrients. 
This approach, often referred to as the "wet landfill," is being evaluated at several locations in the United States. It would allow the landfill to be designed and operated in a way similar to an anaerobic digestion process, would significantly increase the production of methane gas for collection and use as an energy source and would decrease the time for stabilization of the waste. Decreasing the time for stabilizing the waste in the landfill could result in savings in reduced liability and post-closure care periods.

Air emissions are another pollution concern associated with landfills. A landfill emits methane, carbon dioxide and trace amounts of nitrogen oxides, particulates and sulfur oxides. " Methane and carbon dioxide are among the gases that contribute to the international phenomenon of global climate change-the greenhouse effect. Landfills naturally produce methane that, without gas recovery, escapes through passive vents, cracks or extraction systems. If not properly managed through energy recovery or by burning the gas through flaring, methane can cause explosions or fires at the landfill. Approximately 200 landfill sites are recovering or are actively planning to recover landfill gas (LFG) for energy. This option may become more attractive because of 1990 Clean Air Act Amendments (CAAA). Under Section 111 of the CAAA, EPA adopted MSW landfill new source performance and emission guidelines, which require the collection of methane from large landfills-those with $\mathbf{2 . 5}$ million metric tons design capacity, with emissions of greater than 50 megagrams per year. Some landfill operators collect, store and use methane as energy. The amount of revenue received from the energy (methane) collected and used, however, may not outweigh the costs associated with building and operating a methane energy collection and storage facility. Therefore, most landfill operators manage methane by flaring it. States may consider it valuable to provide incentives for productive recovery of this gas as a means of conserving fossil fuels. To date, researchers cannot accurately predict the longevity of methane production and collection at these facilities, but research on the subject continues.

In addition to Subtitle $D$ and the air emissions rule, EPA is working on an effluent standard under the Clean Water Act for landfill leachate, which may be the last fundamental environmental rule-making that directly affects MSW landfills. It will be proposed in the next few years and, by court order, must be finalized by 2000 .

Subtitle D requirements and emission concerns, among other things, have caused a number of landfills to close during the past few years. Approximately 3,197 landfills currently accept MSW; the number has declined from 3,558 in $1994 .^{12}$ Because the capacity of modern landfills is greater than earlier ones, adequate national disposal capacity is not currently a problem; some localities however still may face shortages of local capacity. Reductions in the number of

\section{Landill Minings: A Prospect for the Future}

To extend the capacity of disposal tacinies: a tew landills are being mined to extract buried resolrces and extend the facilites life span's. Landfll nining can accomplish several ends, including exrending the life of existing. landill sites; thus rediucing the need or siling new landilis: decreasing the area requining dosure: remediating an envirommental concem by removing a contaminant sourcer reclaiming marketable recyclables and captining energy ltrough waste: conbustion. Iandfill reclamation, a developing technology. is not without controversy. Critics daim several health and safery issies need 10 he addressed betore ming for example; a fire could start spontaneously from the exposed or decomposing waste or the presence of nethane gas: Pamiculate matter arising from the minimg process could present health problems: if workers are not adequately protected: Despite these concerns; New York has added landill realamation provisions to is solid Waste regulations: and New Jersey has authorized the development of landill nining projects and allocated $\$ 250,000$ from its sanitary landfil contingency fund tor this purpose? is with any waste processing alternative, landill niming and reclanation should be condusted in a nanner to brotect human health and safey and the enviromment.

landfill facilities do not necessarily reflect disposal capacity. In fact, any capacity problems may result instead from the political difficulty of siting new landfills close to the generating region or from the expense involved in shipping out of the region, rather than from a lack of 
available, suitable land for new facilities; inadequate regulations to maintain safety, health and environment standards or a failure of technology to increase capacity. States should therefore, be aware of public concerns and evaluate the overall program costs, transportation and collection issues and environmental implications of landfilling. States need to increase and encourage resource conservation to achieve a sustainable environment. 


\section{Federal ACTIVITIES}

Historically, the federal government's role in MSW management has been minimal. Congress passed the Solid Waste Disposal Act in 1965 to address solid waste management questions. The thrust of this legislation was to move from open dumps to sanitary landfills for solid waste disposal and to encourage state planning. This act did not include any federal regulatory authority. Congress addressed MSW management further with the passage in 1976 of the Resource Conservation Recovery Act (RCRA). Subtitle C of RCRA primarily addressed the regulation of hazardous wastes (mainly industrial and chemical wastes). The federal role in MSW management remained largely advisory. States were left to deal with MSW under their "exclusive regulatory power." It was not until the reauthorization of RCRA in 1984 that the federal government established its regulatory role through Subtitle D, which authorized major revisions to sanitary landfill regulations. Subtitle F of RCRA outlines the federal responsibilities in the application of this law and establishes guidelines for developing agency procurement standards.

Other federal MSW management involvement includes executive orders, federal agency guidelines, congressional activities, Supreme Court decisions and agency information and educational exchanges.

\section{Executive Actions}

Following the lead of several states, President Clinton signed Executive Order 12873 on federal acquisition, recycling and waste prevention in October 1993. This order recognizes the federal government as a consumer with a responsibility to conserve existing disposal capacity through cost-effective waste prevention initiatives and recycling activities. The order requires the purchase of recycled and "environmentally preferable" products and services by the federal government, where cost and product-performance needs are met. The use of such products by federal agencies is meant to "spur private sector development of new technologies and use of such products, thereby creating business and employment opportunities and enhancing regional and local economies and the national economy." EPA is examining several aspects of products such as lifecycle considerations and trade-off issues, the progressing state of technology and functional and site-specific considerations to determine which products are "environmentally preferable."

Similar to state procurement programs, the executive order specifies guidelines for the minimum postconsumer content needed in certain grades of printing and writing paper purchases. Twenty percent postconsumer content was required by December 1994 and increases to 30 percent in December 1998 (Section 504). This guideline, along with other state and federal procurement efforts, sent a strong signal to the paper industry. As a result, new paper and pulp mills using recycled materials have been able to capitalize on federal,
Historically, the federal government's role in MSW management has been minimal. 
state and local "buy recycled" campaigns, mandatory content legislation and government procurement programs.

\section{Congressional Activities}

The last decade has seen increased congressional activity focused on MSW management issues. While keeping MSW management in the hands of state and local governments, Congress, through legislation, encourages the development of rules and regulations by the Environmental Protection Agency.

Congress responded to concerns about the groundwater contamination associated with landfills by including landfill regulatory provisions in the 1984 RCRA reauthorization. RCRA's Subtitle D now governs several aspects of landfill siting, design, operation, monitoring, closure and postclosure.

While keeping MSW management in the hands of state and local governments, Congress, through legislation, encourages the development of rules and regulations by the Environmental Protection Agency.
Congress is examining the merits of flow control in the debate over the Municipal Solid Waste Flow Control Act of 1995 (S 534). If enacted, states, local governments and public service authorities would be allowed to "grandfather" all facilities operating with flow control prior to the Supreme Court's May 16, 1994, Carbone decision. Critics of flow control argue that it interferes with existing recycling arrangements and increases the cost of waste disposal because it limits the free market choice of disposal facilities. At press time, Congress had not made a decision on this bill.

\section{Supreme Court Activities}

Flow control became a national issue when the Supreme Court ruled against it in C\&A Carbone, Inc. vs. Town of Clarkstown (114 Sup. Ct. 1677, 128 L. Ed. 2d 399 1994). The Supreme Court held on May 16, 1994, that a local flow control ordinance was unconstitutional under the Commerce Clause.

To determine if state or local flow control actions violate the Commerce Clause, the Supreme Court considered:

- Whether the action controlling waste flow regulates evenhandedly with only "incidental" effects on interstate commerce, or discriminates against interstate commerce either on its face or in practical effect;

- Whether the action serves a legitimate purpose and, if so;

- Whether alternative means could promote this local purpose as well without discriminating against interstate commerce.

The Supreme Court also ruled that local flow control is within the limits of the Commerce Clause only if a legitimate local purpose is served and there is an absence of nondiscriminatory alternatives. "Legitimate local purposes" are limited to health and safety effects as opposed to economic impacts. ${ }^{13}$ However, states and local governments can refuse to accept solid waste if they are acting as a "market participant." Thus, if a state or local government owns, operates or transacts business itself, it may refuse to accept business from out-of-state sources.

The Carbone decision is one of a series of Supreme Court rulings on solid waste since 1990. The 1992 ruling on Fort Gratiot Sanitary Landfill, Inc. vs. Michigan DNR, 504 U.S. 353 (1992) invalidated a state MSW management law that banned the importation of out-of-state waste. In 1994, The Court struck down differential fees between out-of-state and in-state solid waste in Oregon Waste Systems, Inc. vs. Department of Environmental Quality of 
Oregon, 114 Sup. Ct. 1345,128 L. Ed. 2d 13 (1994). The court's MSW rulings have built upon its 1978 analysis of Philadelphia vs. New Jersey, 437 U.S. 617; 98 Sup. Ct. 2531, 57 L Ed. 2d 475 (1978). In this case, the Court held that state and local governments could not hoard an item of interstate commerce, such as solid waste, for the benefits of their own residents at the expense of out-of-state interests. It was ruled that discrimination against articles of commerce based on geographic boundaries was economic protectionism. ${ }^{14}$

\section{Agency Actions}

The Environmental Protection Agency (EPA) is the main federal agency charged with carrying out federal MSW management laws and developing the resulting in-depth regulations. Federal MSW educational efforts, technical assistance and accompanying grants or loans have been issued through this agency. Yet, state and local government's hold the primary responsibility to regulate MSW. EPA is responsible for drafting and helping implement solid waste management regulations. EPA's issuance of regulations under the Clean Air Act Amendments (CAAA) and RCRA's Subtitle D, for instance, respond mainly to proper use and design of the landfill and MWC facilities. The CAAA regulations are discussed in the energy recovery from waste combustion section.

The regulations developed under Subtitle D affect landfill siting, design, operation, monitoring, closure and postclosure care. New landfill siting is restricted in areas near airports (problems with birds), in floodplains and wetlands, in fault areas and seismic zones and in other unstable areas such as lands subject to mudslides and sinkholes. The design requirements for landfills are more readily adaptable to specific state and local circumstances. Federal regulations emphasize the protection of groundwater and the control of air emissions from landfills as the main design criteria for any new landfill. Operating standards require landfills to exercise greater control in the areas of hazardous wastes, vectors, explosive gases (methane), illegal dumping, water protection, disposal of liquids and air emissions. Many of these specifications can be tailored to the needs of the state and the geography of the site.

Several problems associated with landfills may occur after they have closed. To prevent landfills from being abandoned by the responsible party, Subtitle $D$ regulations have established landfill closure and post-closure regulations. When the landfill is closed, the owner or operator must continue to maintain the final landfill cover and monitor area groundwater and landfill gas to ensure against leakage for a minimum of 30 years after closure. After the owner's and operator's post-closure care duties are completed, the responsibility for the landfill, in some cases, may be returned to the state or local government. Owners and operators of landfills are required to show that they have the financial means to cover the expenses associated with site closure, post-closure monitoring, maintenance and cleanups. Potential options to meet this requirement include insurance, letters of credit and surety bonds, trust funds and net worth. EPA has not finalized its regulation on this topic and the states are acting on their own. More information can be obtained from the EPA's Criteria for Solid Waste Disposal Facilities: A Guide for Owners/Operators.
The Environmental
Protection Agency
$(E P A)$ is the main
federal agency
charged with
carrying out fed-
eral MSW man-
agement laws and
developing the
resulting in-depth
regulations. 


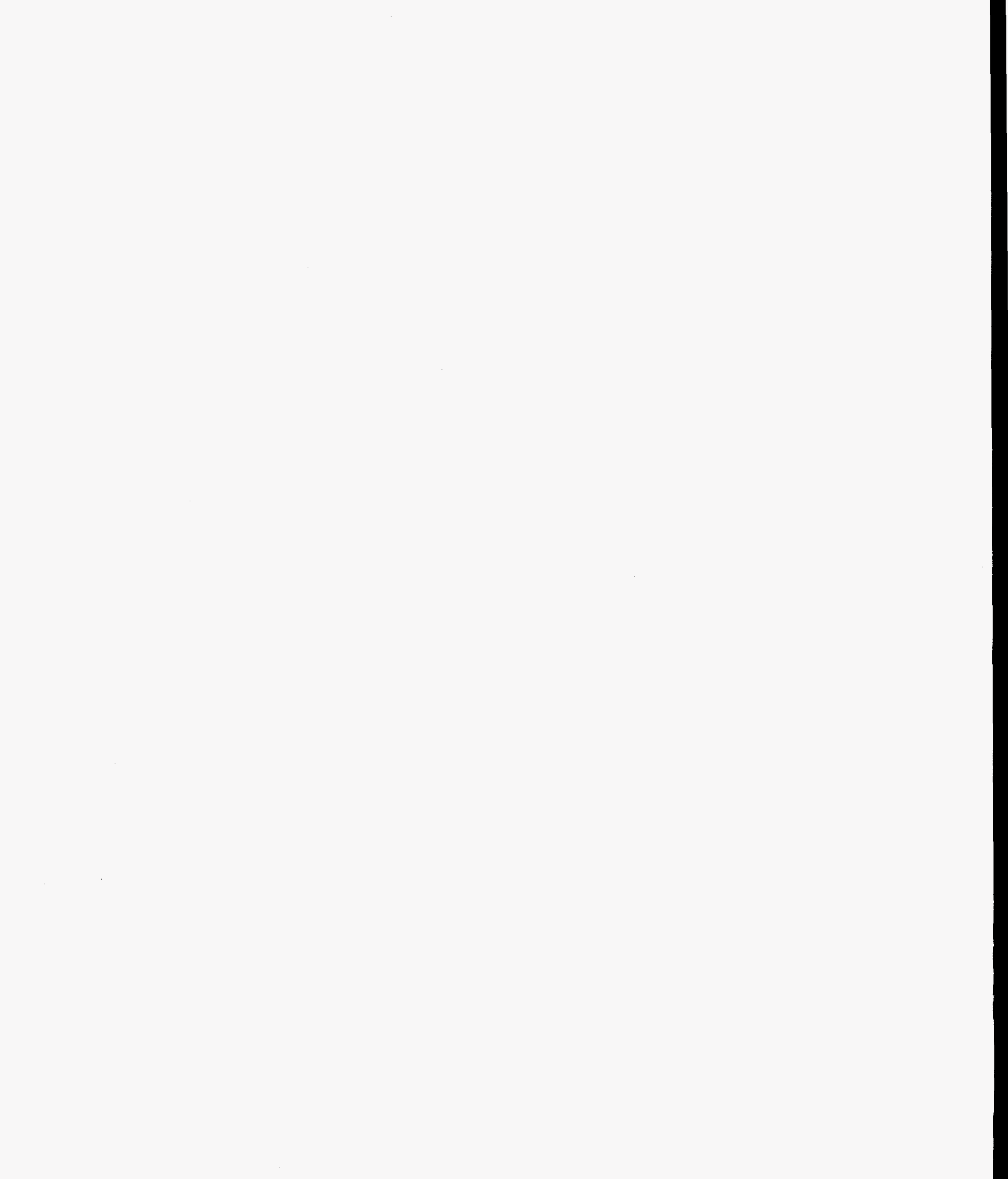




\section{State LAWS AND LOCAL ACTIVITIES}

Responsibility to regulate MSW is not new to state and local governments. Originally, many state and local programs focused on regulation or were tailored to meet specific needs. Now, comprehensive approaches to MSW management are common. This is due, in part, to the fact that states must now widen their scope to take a holistic view of environmental management. The Subtitle $D$ regulations also have caused states to reevaluate their disposal capacities and, in doing so, to develop more long-range comprehensive state MSW management plans. The environmental management roles of state government, however, essentially remain the same: State governments develop policies and regulate MSW programs, and local governments provide MSW management.

\section{State and Local Planning Requirements}

Successful MSW management depends upon a cooperative partnership among state and local governments (or regional solid waste authorities), the private sector and individual citizens. This cooperation depends in part upon an MSW management plan that clearly defines the roles of stakeholders in achieving state goals and objectives. Several components should be considered in comprehensive MSW management planning process. Initially, a state must assess its role in MSW management. A number of factors should be considered when performing this assessment. The wider its scope, the easier it will be to address questions that arise in the planning process. States need to identify and prioritize state MSW goals and objectives. A goal should state the desired outcome of the MSW program and include a clear purpose. Objectives outline the steps proposed to meet the goal and are used to measure the progress of the program. State goals and the programs designed to reach those goals can be either mandatory or voluntary. Mandatory solid waste reduction or recycling goals can create tension between state and local governments. Some local governments consider mandatory state MSW goals "unfunded mandates." However, these mandates can include measures to reduce disposal costs for municipalities. For example, landfill yard waste bans may encourage grass mulching. Before developing any comprehensive MSW management plan, states should consult with their communities, consider funding mechanisms for MSW management and examine the infrastructure for program implementation.

Also as part of their assessment or planning, states should inventory and evaluate available resources. These include natural resources such as land, groundwater and public and private MSW management capabilities. Such an inventory, for example, allows a state to determine whether space exists for landfill technology, if changes are needed in state or local staffing and funding or if the existing infrastructure is equipped to implement the program.
Successful MSW management de- pends upon a cooperative part- nership among state and local governments, the private sector and individual citizens. 
MSW planners also must strategically evaluate the management options in comparison with state MSW needs, goals and infrastructure abilities. The options should be evaluated on technical, environmental and economic grounds to determine which is best suited to individual state and local circumstances. When all options have been evaluated, several are likely to be chosen as the basis of the state's integrated MSW management system. Once the options most suited to the state's needs and local conditions are chosen, a state can begin to define its management system. This may include only a few options-source reduction and landfilling, for example-or it may encompass all management techniques. This cooperative effort between state and local governments may result in a variety of ISWM plans within the state.

States also must develop an implementation strategy for their MSW management policies that takes into account other planning processes. The implementation strategy should offer direction for program implementation and define the means by which the program's progress will be measured. It also must take into consideration the process to be followed for procurement, development of facilities, funding, administration and operation and decision making. For example, enforcing Subtitle $D$ requirements is important. During MSW management planning, state and local governments must evaluate financial assurance responsibilities for public and private facilities, whether they are used for recycling, composting, waste-to-energy or landfill disposal. Such assurance must be assessed not only for the life of the disposal option chosen but also for expenses that may occur after the facility closes.

\section{Capacity Assurance}

It is in the state's best interest to take a proactive approach to MSW planning by investigating the standards that govern existing facilities.
The solid waste "crisis" of the 1980s developed because some states perceived that MSW landfill capacity was diminishing rapidly. They did not realize that the market would adjust and increase the available capacity for MSW management. In fact, new and adequate capacity became available as the price increased. Based on such experience, it is important that states adjust their solid waste management plans to provide future capacity flexibility for landfilling through an ISWM system comporised of recycling, MWC and composting. Each of these management methods needs to be evaluated to determine the facility's remaining or predicted life span. The determination of disposal capacity varies among all of the states and can significantly affect each state's overall MSW management plan.

Even if it seems that existing landfill capacity is sufficient for the foreseeable future, states need to ensure the environmental integrity of facilities. Both closed and monitored facilities have long-term liability concerns. Such concerns may be reduced because new facilities, that fall under Subtitle D standards, require financial assurance and post-closure monitoring. However, states can be ultimately responsible for the long-term care of the facility if the owner or operator defaults. Depending on the circumstances, this fact may be reason enough to consider siting alternative disposal facilities or shifting emphasis from disposal to conserving resources. In any case, it is in the state's best interest to take a proactive approach to MSW planning by investigating the standards that govern existing facilities.

\section{Management Costs}

Because of stringent environmental regulations, some capacity shortages and increased recycling, the overall cost of waste services has increased in most areas of the country. It is difficult, however, to obtain a national or regional estimate of the average solid waste capital costs and the costs associated with the operation and maintenance of MSW facilities because several variables can cause an increase or decrease in rates at a specific facility. Compounding the measurement barriers, it is difficult to determine the collection, hauling 
and transportation costs that are borne by a variety of public and private entities in a given region. Because all entities are not necessarily involved in operating the area's disposal facilities, it is difficult to establish comprehensive management costs, even as estimates. Collection costs, for example, can be affected by crew size, union contracts, equipment used, distance between houses, the distance from a centralized disposal facility and state and local fees and taxes. A well-organized solid waste management system can adjust the pricing structure to provide for cost sharing.

States must examine not only existing costs of MSW disposal but the economics of future capacity assurance as well. This involves considering such factors as costs of siting disposal facilities, financing for those facilities, transportation costs and facility monitoring and postclosure care. Many of these costs can be shared by public-private MSW management partnerships initiated by local or regional solid waste authorities.

The level of service chosen in a state integrated waste management program will directly affect the costs associated with the program's implementation. Communities need to identify opportunities to reduce management costs without limiting service. Although shortterm costs of one management option may seem to be less expensive, MSW planning requires an assessment of the long-term costs of the overall system.

\section{Regionalization}

Since local governments have shouldered the bulk of the responsibility for MSW management in the past, it seems only logical that a partnership between states and local governments would be formed in a comprehensive MSW management plan. Through the MSW planning process state and local governments can evaluate the potential for implementing a regional MSW management program. Regionalization of MSW management offers several benefits. Certain areas of the state may have their own solid waste generation patterns that are better addressed by a regional, rather than a statewide, approach. A large, urban area, for example, may have different MSW needs than several smaller, rural counties. Similarly, markets for recyclable materials can differ throughout the state. Border towns may find better market opportunities in neighboring states, whereas interior cities may be more likely to find markets within the state. Regionalization can make MSW management services more efficient by eliminating the duplication of services by each municipality, thereby allowing better economies of scale. Geography and resources may vary within a state. Regionalization accounts for these differences in MSW management planning.

When considering regionalization of MSW management, states need to evaluate alternative strategies for allocating responsibilities through existing governmental units, examine the possibility of creating new regional solid waste authorities and establish methods to ease the formation of regional authorities.

\section{Financing and Revenues}

MSW management planning also must determine how proposed methods will be funded. Because the ownership of MSW facilities and collection services can be public or private, the type of ownership affects financing choice, project implementation and procurement of materials and operation.

Privately owned facilities can be financed through private equity. This option appeals to many local government and solid waste authorities because it removes much of the risk associated with long-term debt. This equity may be gathered through a conglomeration of

Throughout the
MSW planning
process state and
local governments
can evaluate the
potential for
implementing a
regional MSW
management
program.


interests that want a sound investment return from the project. Privately owned facilities often are financed with traditional loans from commercial lenders. Short-term loans are acquired for the construction phase of the project, whereas permanent lenders provide financing after the project is operational.

Tax-exempt bonds issued by a government agency are an alternative to traditional, taxable debt. The interest rate paid on these bonds is generally a few percentage points lower than that of traditional loans. A government entity can issue two types of tax-exempt bonds: general obligation bonds (GO) and project revenue bonds. General obligation bonds allow a state or local government to pledge the full faith, credit and taxing power of the issuing government body. This pledge translates into using the state's or local government's taxing authority to repay the bondholders should the proposed revenue stream fail. These bonds are considered the most secure form of debt. Voter approval sometimes is required to issue such bonds, which may make them difficult to issue during recessionary periods. Public ownership of the project is required when GO bonds are used. ${ }^{15}$

Project revenue bonds are not as secure as $\mathrm{CO}$ bonds and, therefore, have higher interest rates that fluctuate with market conditions and state or local bond ratings. Project revenue bonds are secured from the revenues of the project being financed. As a result of the federal Tax Reform Act of 1986, there are two types of project revenue bonds: government purpose bonds (GPBs) and private activity bonds (PABs). For GPBs to be issued, the project must be publicly owned. There also are limitations on the sale of project outputs to private businesses. In addition, the private operation of any part of the project must not exceed five years and may be canceled after two years with no penalty. PABs also are subject to certain restrictions, but allow for private ownership and operation of an MSW management project. States have an annual allotment of PABs. The annual maximum PAB is equal to $\$ 50$ multiplied by the state's population or $\$ 150$ million, whichever is greater. PABs are the only means by which a privately owned project can obtain tax-exempt funding. ${ }^{16}$ Taxexempt financing that is not subject to the PAB volume cap is available for solid waste management projects when the facility is owned by a public entity. The five-year limit on private management or operation of such a facility does not apply.

Taxable bonds are another method for financing MSW management projects. Taxable municipal bonds can be used to finance publicly owned projects that do not qualify for PABs. Although taxable municipal bonds have higher interest rates than tax-exempt bonds, they offer a more favorable depreciation period on solid waste equipment. This can offset the higher interest cost.

When developing a state MSW management strategy, it may be helpful to include grants and loans to help local governments, private entities and citizen groups with program implementation. Grants and loans can be used to develop recycling programs, research uses for post-consumer material and purchase equipment for processing recyclable materials. Programs must be developed to operate independent of the grants, however, because grants may not always be available.

Various alternative financing options are available to help states supplement MSW assistance programs. Surcharges on tipping fees or other user fees provide money to publicly fund MSW management projects, either locally or statewide. Revenues generated by the sale of recyclable materials often can help offset program costs. In some areas, municipalities have removed MSW operations from the general fund, where the costs of MSW may have been bundled with other general municipal services costs. Doing this helps to ensure cost recovery, ensures a more equitable distribution of costs of MSW management services and helps the municipality better understand, manage and report the costs. Some municipalities have begun to account for MSW management services as a separate 
"enterprise fund" with its own capital program and system of fees and charges. Enterprise funds typically use full cost accounting to properly estimate current and future costs of MSW management. Whether enterprise funds are used, however, full cost accounting is a valuable tool to ascertain current and future MSW management costs.

Establishing a fee-for-service arrangement based on system-wide costs and benefits as determined through full cost accounting can help the public become more aware of the costs of waste management. One approach being used by some local and regional solid waste authorities is unit pricing, also known as "pay-as-you-throw." This method charges customers for the amount of waste they dispose. The less they produce, the less they are charged-a simple market approach to MSW management. Citizens can be charged based on the volume or weight of the waste. This method of pricing establishes a direct link between consumer behavior and the cost of MSW. Even though some communities that use this method report a 90 percent approval rating, there can be drawbacks; communities may need to develop creative implementation strategies, deal with increased illegal dumping and carefully monitor costs.

\section{Risk Assessment}

The difficulty states face in assessing risks associated with various MSW management technologies is that no standardized methodology exists to calculate risk. As a result, people disagree more about the definition of risk than about its severity. EPA offers a threepart model for risk assessment that provides helpful guidance for state policy development. This model uses risk assessment, management and communication.

The most important element of EPA's three-tiered model is risk communication. This involves addressing both real and perceived risks and understanding that risks can be involuntary. Much of the public concern about MSW management-related risks stems from problems engendered by post legal contaminant disposal and a lack of understanding about the scientific complexities of specific disposal methods. When the management approaches are explained in

\section{EPA's Seven Rules of Risk Communication}

1. Accept and involve the public as a legitimate partner.

2. Carefully plan and evaluate MSW management efforts.

3. Listen to the public's specific concerns.

4. Be honest, frank and open with the public.

5. Coordinate and collaborate with other reliable sources.

6. Address media questions and keep lines of communication open.

7. Be clear, open and concise in communication.

lay terms, the public can become an integral and supportive part of the MSW management process. Although conflicting views will exist, the discussion of risks and how to address them can move forward only when all affected parties have a basic understanding of the issues.

The potential risks of MSW management technologies are lowered exponentially when states require the use of the "best available technology" (BAT) in each management method to achieve maximum environmental protection. Just as landfills have evolved from open dumps to lined, engineered landfills with pollution monitoring systems, every other method of managing $\mathrm{MSW}$ is improving its pollution prevention technologies and reducing its 
As a result of the public sector's desire for integrated management, the private sector is willing to provide various components, such as curbside collection of recyclables and $M W C$, as long as the public sector is willing to cover the private sector's risk. potential risks. States need to consider which management methods have the BAT most suited to deal with existing and future MSW needs.

The siting of facilities is one example of how states can use the risk assessment model. The nature of MSW facility siting issues is multidimensional. Each dimension needs to be examined by states and local or regional solid waste authorities. The potential environmental and health risks associated with recycling, landfilling and combustion need to be addressed in such a way that the public is confident about the method selected and the facility's site. Economic issues that range from the perception of decreasing property values near the site to funding of the site and facility may be examined. Social issues such as equity in siting processes and future land uses are another aspect of the siting process. Political concerns, including the responsibility for site management or monitoring, are a final factor of the siting equation. By involving individual citizens and their organizations as well as the private sector in MSW management planning, states can begin to address siting issues before they become problems.

For this reason, state legislators must be aware that risk assessment of the technological impacts of MSW management approaches is an important component of any state MSW management program.

\section{Private Sector Role}

The role of the private sector in solid waste management continues to grow as entrepreneurial opportunities expand due, in part, to the reliance on an integrated waste management approach. As a result of the public sector's desire for integrated management, the private sector is willing to provide various components, such as curbside collection of recyclables and MWC, as long as the public sector is willing to cover the private sector's risk. If risk coverage is not ensured, however, the private sector may haul the MSW to the cheapest landfill. In many cases, solid waste has become as subject to market conditions as any other commodity. For example, companies dealing in recycled materials faced a serious price glitch during the early stages of widespread public support for recycling. Many of those that remained in the industry, however, have received some good returns on their investment as market value for certain recycled goods has fluctuated during the past 10 years.

This public/private partnership in solid waste management is mutually beneficial. Solid waste management services, in some form, have become an expected public service. State, regional and local solid waste authorities have found that by privatizing many aspects of these services, however, they are better able to provide the most economically efficient means of dealing with the waste stream. Organized free market competition can ensure that the public is getting the most for its money. Government solid waste authorities remain active partners with private corporations in such instances. Government officials oversee the implementation of solid waste programs and continue to assess the solid waste management needs of the community or state and act to meet those needs.

\section{Public Involvement and Acceptance}

Individual citizens usually do not become involved in MSW management until a program already is implemented unless they have concerns about facility siting or MSW management technology. States therefore need to make special provisions to ensure that citizens have the opportunity to be active participants in every aspect of the process. Not only will this help states avoid problems with program implementation, it also will increase 
the chance of long-term program success. There are several steps a state can follow to ensure maximum public participation in the planning procedure.

Initially, the "public" must be defined. Everyone in the state will be affected by MSW policies and programs; however, interest in the policies will vary among individuals. Those living in communities with old landfills on the Superfund list, for example, may express more interest in MSW policies than a community with a successful variable-rate collection program. In either case, states may need to offer a variety of options to allow people to participate at their own level of interest and expertise. As the policy and program implementation process continues, the public interest will change as well. Some citizens may take little interest in the policy process but may participate in program implementation. States need to take the dynamic nature of the MSW management issue into account when developing a public involvement plan.

Techniques for involving the public can be divided into two categories. Information techniques provide information to the public and participation techniques are used to extract information from the public. Information techniques include briefings for public officials and agencies, feature stories and newsletters. Participation techniques include advisory groups, focus groups, hearings, meetings and polls. Effective involvement results from using a combination of these techniques.

One problems that states face in public involvment with MSW management is the perceived lack of credibility of technical information. Interested citizens can feel like outsiders if they do not understand the "jargon" of the planning discussion. This lack of understanding can quickly lead to distrust. The demystification of technical language is especially important to ensuring that the public can be an equal partner in MSW management facility siting decisions. A solid understanding of the information on potential sites and studies of the options will help citizens to work with government and the private sector to reach a rational agreement about which options are best for the community.

Whereas selected citizens may take a real interest in the MSW management planning process, it is important that a majority of the public be involved in MSW program implementation. Many states allow local or regional governments to implement MSW programs so that processes can be tailored to individual community needs. To be effective, the public education phase of program implementation should be positive and provide simple instructions about participation. Local or regional solid waste authorities typically have a more complete understanding of their audiences and how they receive information. For example, some communities may need bilingual information about the MSW program. Local media outlets can be used to deliver public service announcements about various program activities as well. Once individuals become aware of their responsibilities for MSW management and of the positive aspects of their participation, they are more likely to take an active role to make the programs successful.

\section{Performance Measurement}

When states begin to develop an integrated approach to manage MSW, they sometimes want to compare their program with other states and the nation as a whole. Such comparisons can complicate states' efforts and, in some cases, can be counterproductive. Making comparisons therefore may not be worth undertaking. Because national uniform performance measures have yet to be established, a review of other programs can be more useful as a guide for state policy development. Due to the measurement discrepancies, some states choose not to set numerical recycling goals. When Wisconsin proposed its recycling law, for example, some were concerned about how to accurately measure
Many states allow

local or regional governments to implement MSW programs so that processes can be tailored to individual community needs. 
With deliberate MSW policy and program evaluations, states can gauge the progress toward their overall solid waste management goals and objectives while examining their relevance within the context of current state solid waste management needs. progress toward meeting recycling goals and the potential for tying up municipal auditors in endless "bean-counting" exercises. As a result, Wisconsin decided not to establish numerical goals for its recycling program.

Because several states have experienced frustration with trying to "measure" their progress toward specific numerical goals, states that expect to measure their progress should carefully determine and establish a baseline from which to measure progress. Many states have yet to establish such a baseline and, therefore, have difficulty documenting their efforts.

\section{Policy and Program Evaluations}

Hundreds of solid waste management laws have been enacted over the years; most of these laws aim to achieve a specific outcome. Many of the laws have not been reviewed or evaluated since they were enacted. Is it time to evaluate whether these laws have met the intent prescribed by the state legislature? With deliberate MSW policy and program evaluations, states can gauge the progress toward their overall solid waste management goals and objectives while examining their relevance within the context of current state solid waste management needs. For a state to comprehensively understand the effectiveness of its MSW efforts, MSW policies and programs need to be evaluated periodically for a variety of reasons:

- Evaluations allow states to determine if the initial and overall MSW management goals set forth in public policy are still relevant, or if circumstances warrant a restructuring of goals.

- They permit states to ascertain whether the MSW programs meet the established policy objectives.

- They can help determine economic efficiency of an MSW program through an evaluative process as well.

States can conduct formal or informal evaluations of their MSW policies and programs. Formal policy evaluations include oversight hearings and a thorough assessment of the policy and formal program evaluations or audits usually are conducted by staff who specialize in evaluations. Less formal, but more frequently used evaluation methods include agency reviews and recommendations; feedback from interest groups; media coverage of the problem, policy and program and constituent comments and complaints. Formal program evaluations, conducted by professional auditors and evaluators, typically follow government auditing standards prescribed by the comptroller general of the United States or the American Evaluation Association's guiding principles for evaluators.

Formal MSW program audits can be carried out by public agencies or contracted external auditors. Informal evaluations of state MSW policies and programs are more flexible. Legislators, their staff's and committees may be directly involved in such informal efforts. The appropriateness of either type of evaluation depends upon several factors, including the age of the program in question and the political situation surrounding the need for an evaluation. When an evaluation is completed, legislators should be prepared to respond to its findings and recommendations. For more information about MSW policy and program evaluations, see NCSL's Environmental Partners' Guidelines to Evaluate State Solid Waste Management Policies and Programs. 


\section{Management of Special Wastes}

States face unique problems and opportunities with the management of special wastes. Because of their nature, special wastes normally are not collected and disposed with the rest of the waste stream. They include items such as household hazardous waste, tires and white goods.

Household hazardous wastes. All of us, at times, use various chemicals for cleaning, pest and weed control and other purposes. When stocks of such chemicals are no longer useful to the household, they become "household hazardous wastes" (HHW) when they are discarded with other residential solid wastes. Most states do not have explicit laws that prohibit the disposal of HHW. Consumers therefore are allowed to discard HHW in residential solid waste containers. EPA regulations allow small amounts (up to 220 pounds per month per family or small business) of unwanted chemicals to be disposed in a solid waste system. Nevertheless, most states encourage the active separation, collection and safe disposal of unwanted chemicals.

It is a good practice to separately collect small quantities of unwanted household chemicals, old gasoline, kerosene, pool chemicals, pesticides, paint, ammunition, batteries, laboratory chemicals, old drugs and oil-based paints because it will gradually reduce metals and complex hydrocarbons, result in less danger to workers collecting solid wastes and decrease the chance of groundwater pollution, even though modern lined landfills can safely accept such wastes. Separate collection can be expensive. Therefore, long-term costs and benefits should be considered. When substantial quantities of such chemicals are collected and stored, they are regulated by certain EPA regulations.

The proper disposal of household hazardous waste can be addressed through local and regional solid waste authorities in conjunction with state environmental agencies. These authorities can conduct community education efforts to raise awareness about the importance of using less hazardous alternatives, separating these toxins from the waste stream and disposing of them properly, thereby reducing the purchase and use of hazardous household products generally. Communities may offer specific collection days for these wastes or establish permanent collection sites at the local recycling center. These efforts can sufficiently minimize adverse impacts from inappropriate disposal.

Tires. More than 200 million tires are disposed of each year. Tires can cause a variety of problems in the solid waste stream. They occupy a large volume of space in the landfills, tend to "rise" in landfills and eventually break the cover. When tires are stockpiled, they can become the source of large, difficult-to-extinguish, noxious fires. Stockpiles provide breeding grounds for mosquitoes and other disease-spreading vermin. To combat these problems, 33 states (Arizona, Arkansas, California, Delaware, Florida, Georgia, Hawaii, Idaho, Illinois, Indiana, lowa, Kansas, Kentucky, Louisiana, Maryland, Massachusetts, Minnesota, Mississippi, Missouri, Nebraska, New York, North Carolina, Ohio, Oklahoma, Oregon, South Carolina, South Dakota, Tennessee, Texas, Utah, Vermont, West Virginia and Wisconsin) have banned whole tires from landfills to encourage alternative disposal. Ten of those states-Delaware, Hawaii, Illinois, Indiana, lowa, Kansas, Kentucky, Missouri, New York and Oklahoma-allow tires to be disposed of if they have been shredded. Some landfill operators, however, do not accept tires because of business practices.

Several methods exist for using tires, thus diverting them from disposal. For example, tires often are processed into tire-derived fuel. Some tires can be retreaded and some others can be shredded to create crumb rubber for repaving asphalt roads. When appropriate, tire
The proper disposal of household hazardous waste can be addressed through local and regional solid waste authorities in conjunction with state environmental agencies. 
States can address the handling of white goods through voluntary initiatives, public education, technical assistance to local and regional solid waste authorities, legislation such as landfill bans, private sector/market forces, deposit or return systems and public/private partnerships. chips can be used as fill material in landfills and other civil engineering projects. However, crumb and chip rubber tires have to compete with other materials that are generally less expensive. Because there has not been enough experience with reuse of tire material, however, states must understand the drawbacks of improper use of the material. States can examine all these options during the MSW management planning process and determine the role they may be able to play in creating a market for used tires. Some states could evaluate regional solutions with neighboring states by using scrap tires as fuel in energy recovery plants. If states do not want to become directly involved in tire reclamation, they may include tires as well as other special wastes in state recycling research and development grants and loans.

White goods. The term "white goods" usually refers to items such as inoperative or discarded commercial and domestic large appliances-such as refrigerators, stoves and washers. Before 1990, the primary environmental concern with landfilling white goods was the possible release of, and future contamination from, chlorofluorocarbon (CFC) gases, polychlorinated biphenyls (PCBs) and hydrochlorofluorocarbons (HCFCs). CFCs and HCFCs both are considered ozone-depleting coolants, are found in refrigerators, freezers, automobile air conditioners and other cooling appliances. PCBs, suspected carcinogens, are oily fluids used in electrolytic substances in a small percentage of capacitors that were manufactured before 1979 and are found mainly in microwaves and air conditioners. The 1990 Clean Air Act Amendments addressed these concerns by mandating the removal of CFCs and HCFCs before landfilling and recycling of such appliances.

Despite the removal of these chemicals, landfilling of white goods nevertheless remains a concern. White goods are worth separating and recycling as compared to landfilling them. In a landfill they will not biodegrade; by recycling, better use can be made of our discarded material. Second, white goods are being diverted from landfills because of the value of and need for the scrap metal associated with them. By weight, 75 percent of white goods are made from steel. According to the Steel Recycling Institute, the steel used in new appliances contains 25 percent recycled steel. In 1995, 74.8 percent of all appliances entering the waste stream were recycled.

Generally, state programs to address the disposal of white goods can be placed into two categories: mandatory recycling and technical assistance. Eighteen states currently ban white goods from disposal in landfills (Arkansas, California, Florida, Hawaii, Illinois, Louisiana, Massachusetts, Minnesota, Missouri, Nebraska, North Carolina, North Dakota, Oregon, Rhode Island, South Carolina, South Dakota, Vermont and Wisconsin). In addition, Virginia landfill operators are authorized to decide whether to accept appliances after CFCs and HCFCs have been removed. States that do not have a landfill ban on white goods generally separate appliances from the waste stream and recycle them. The value of the steel scrap has ensured market demand for the recycling of these goods. Many landfills do not accept white goods as a matter of business practice.

States can address the handling of white goods through voluntary initiatives, public education, technical assistance to local and regional solid waste authorities, legislation such as landfill bans, private sector/market forces, deposit or return systems and public/private partnerships. Such programs, should increase the recycling of white goods and decrease the amount of litter resulting from illegal disposal practices. 


\section{DISCUSSION}

MSW management questions have been mainly a microeconomic issue, micro in the sense that management decisions were confined to a locality, or an intrastate area or a geographical region. Two trends are converging to change this microeconomic focus to a macroeconomic issue: the presence of "mega" landfills in sparsely populated areas, which makes transportation of solid wastes across several states a daily reality; and the growing concern of a number of interests for consideration of the MSW stream in an overall resource management framework. These two phenomena bring a wide range of cost impacts: "mega" fills appear to offer very cheap disposal; considering MSW as part of our resource base has proven expensive.

Further, we now have an almost dual system of supplying needed MSW disposal capacity. On the one hand, states have historically required or authorized local governments to protect public health and welfare, that is, provide for MSW services, beginning with collection and continuing logically through final disposal. Unfortunately, confusion about the effect of the Supreme Court decisions regarding flow control, (especially the May 1994 Carbone decision) remains. But flow control is merely a symptom of the larger question, which is responsibility for public health and welfare as it relates to delivery of integrated MSW management-who is in charge?

States now find themselves with a historic opportunity-and a responsibility - to give careful consideration to appropriate state, local and private sector roles in provision of integrated MSW management services and capacity and the degree to which future intergovernmental cooperation on these issues will be necessary. Ultimately, the states will be responsible for all closed landfills. Therefore, the states must provide long-term planning and implementation, cooperate with local governments and allow private enterprises to participate in the program.

\begin{tabular}{l} 
States now find \\
themselves with a \\
historic oppor- \\
tunity-and a re- \\
sponsibility - to \\
give careful con- \\
sideration to ap- \\
propriate state, \\
local and private \\
sector roles in \\
provision of inte- \\
grated MSW \\
management ser- \\
vices and capacity \\
and the degree to \\
which future inter- \\
governmental \\
cooperation on \\
these issues will \\
be necessary. \\
\hline
\end{tabular}

States now find themselves with a historic opportunity-and a responsibility-to give careful consideration to appropriate state, sector roles in provision of integrated MSW management services and capacity and the degree to which future intergovernmental cooperation on be necessary. 


\section{NOTES}

1. U.S. Environmental Protection Agency, Characterization of Municipal Solid Waste in the United States: 1995 Update (Washington, D.C., 1995), 3.

2. Ibid.

3. Ibid.

4. Robert Steuteville, "The State of Garbage in America," BioCycle (April 1996): 54.

5. Chaz Miller, "Recycling in the States: 1994 Update," Waste Age (March 1995): 93.

6. Robert Steuteville, "The State of Garbage in America," BioCycle (April 1996): 54.

7. Robert Steuteville, "The State of Garbage in America," BioCycle (April 1996): 54.

8. U.S. Environmental Protection Agency, Characterization of Municipal Solid Waste in the United States: 1995 Update (Washington, D.C., 1996), 6.

9. Michael Malloy and Cheryl McAdams, "The U.S. and Internationa! Municipal Waste Combustion Industry," Waste Age (November 1994): 92.

10. John T. Aquino, "Landfill Reclamation Attracts Attention and Questions," Waste Age, (December 1994): 63.

11. Franklin \& Associates, The Role of Recycling in Integrated Solid Waste Management to the Year 2000, prepared for Keep America Beautiful (Stamford, Conn., September 1994): 1-8.

12. Robert Steuteville, "The State of Garbage in America," BioCycle (April 1996): 54.

13. James E. Kundell, Deanna L. Ruffer and Steffney Thompson, "Solid Waste Flow Control (Designation)," a paper presented at the Conference of Southern County Associations Regional Solid Waste/Environmental Network (March 1993): 3.

14. Bruce Parker, "Supreme Court Finds Clarkstown Flow Control Law Unconstitutional," Waste Age (June 1994): 21.

15. Larry Morandi, and Sam Azodmanesh, "Financing Water Quality Infrastructure: An Update on State Revolving Funds," State Legislative Report 17, no. 20 (Denver, Colo.: National Conference of State Legislatures, October 1992): 5.

16. Nicholas S. Artz and Jacob E. Beachey, "Financing and Life-Cycle Costing of Solid Waste Management Systems," in Handbook of Solid Waste Management, Frank Kreith, ed. (New York: McGraw-Hill, 1994): 14.6. 


\section{GLOSSARY OF TermS AND ACRONYMS}

Definitions may differ slightly among the states

ADF: An advanced disposal fee is a surcharge on a specific product in advance of its disposal to generate revenues that will subsidize or offset the ultimate cost of its disposal. In addition, it is meant to encourage waste reduction in production and consumption. ADFs are item-specific and include both products and materials. ADFs include both disposal and recycling costs.

Ash: The mineral content of a product that remains after complete combustion. *

Bottom ash is the nonairborne combustion residue from burning fuel or waste in a boiler. The material falls to the bottom of the boiler and is removed mechanically. Bottom ash constitutes about 90 percent of the total ash created by the combustion of solid waste. ${ }^{* *}$

Fly ash is all solids, including ash, charred papers, cinders, dusty soot or other matter that rise with the hot gases from combustion rather than falling with the bottom ash. Fly ash is suspended in the flue gas after combustion and can be removed by pollution control equipment. **

Bailing: Compacting solid waste into blocks to reduce volume and simplify handling. *

Biodegradable: A substance or material that can be broken down into simpler compounds by microorganisms or other decomposers such as fungi. **

Biomass: All of the living material in a given area; in MSW, often refers to vegetation. *

Bottle Bill: Proposed or enacted legislation that requires a returnable deposit on beverage containers and provides for redemption at retail stores or other sites. Such legislation, also known as beverage container deposit legislation, is designed to discourage the use of throw-away containers. *

CERCLA: Comprehensive Environmental Response, Compensation and Liability Act of 1980 . Also known as "Superfund." Act to clean up the abandoned or inactive hazardous waste dump sites.

Clean Air Act: An act passed by Congress to have the air "safe enough to protect the public's health" by May 31, 1975. Established the National Ambient Air Quality Standards (NAAQS) for major primary air pollutants and the control of emissions and hazardous air pollutants from certain sources. Codified at 42 USC 74d, et seq.

Clean Water Act: A federal law enacted with the goal to protect the nation's water resources. Requires EPA to establish a system of national effluent standards for major water pollutants. Requires all municipalities to use secondary sewage treatment by 1988. Sets interim goals of making all U.S. waters safe for fishing and swimming. Requires effluent limits and permits for point-source discharges of pollutants into waterways only with a permit from EPA. Requires all industries to use the best practical technology (BPT) for control of conventional and nonconventional pollutants and to use the best available technology (BAT) that is reasonable and affordable. Requires EPA to address nonpoint-source pollution and to establish water quality standards. Codified at 33 USC 1251, et seq.

Cocollection: The collection of ordinary household waste in combination with that of source-separated recyclables.

Coding: In the context of solid waste, coding refers to a system to identify recyclable materials. The coding system for plastic packaging uses a three-sided arrow with a number in the center and letters underneath. The number and letters indicate the resin from which each container is made: 1=PETE (polyethylene terephthalate), 2=HDPE (high-density polyethylene), 3=V (vinyl), 4=LDPE (low-density polyethylene), $5=P P$ (polypropylene), 6=PS (polystyrene), $7=$ other plastics. The code is molded into the bottom of bottles that have a capacity of 16 ounces or more and other containers that have a capacity of 8 ounces or more. **

Combustion: The controlled burning of waste, in which heat chemically alters organic compounds, converting them into energy. Inorganics in the waste become ash. The process is commonly used to reduce volume and produce energy (waste-to-energy). *

Mass Burn: The combustion of municipal solid waste (in a furnace or boiler system) without prior sorting or processing. ${ }^{* *}$ 
Refuse-Derived Fuel: The combustible or organic portion of municipal waste that has been separated and processed for use as fuel. RDF can be burned with or without other fuels such as coal in a variety of forms (shredded, fluff, densified pellets etc.). **

Commercial Waste: All solid waste emanating from business establishments such as stores, markets, office buildings, restaurants, shopping centers and theaters. *

Commingled Recyclables: Mixed recyclables that are collected together. *

Composite Liner: A liner for a landfill, composed of both a plastic and soil component. **

Composting: The controlled biological decomposition of organic material in the presence of air to form a humus-like material that can be used as a soil amendment. *

Solid Waste Composting: The controlled degradation of municipal solid waste that is usually pre-sorted to remove noncompostable materials. ***

Yard Waste Composting: The controlled degradation of leaves, grass and brush. ${ }^{* * *}$

Cost/Benefit Analysis: A quantitative evaluation of the costs that would be incurred by implementing an environmental regulation versus the overall benefits to society of the proposed action. *

Construction and Demolition Debris: Waste building materials, dredging materials, tree stumps and rubble resulting from construction, remodeling, repair and demolition of homes, commercial buildings and other structures and pavements. Materials may contain lead, asbestos or other hazardous substances. *

Cover Material: Soil or other material used to cover compacted solid wastes in a sanitary landfill. ${ }^{* *}$

Cullet: Clean, generally color-sorted, crushed glass used to manufacture new glass products. **

Curbside Collection: Collection of recyclable materials at the curb, often from special containers, to be brought to various processing facilities. Collection may be of both separated or mixed wastes. ${ }^{* *}$

Decomposition: The breakdown of organic wastes by bacteria, chemical or thermal means. Complete chemical oxidation leaves only carbon dioxide, water and inorganic solids. ${ }^{* *}$

Degradation: (also biodegradation) A natural process that involves assimilation or consumption of a material by living organisms. ${ }^{* *}$

Deinking: The removal of ink, filler and other nonfibrous material from printed waste paper. ${ }^{* *}$

Demand-Side Waste Management: Consumers use purchasing decisions to communicate to product manufacturers that they prefer environmentally sound products that are packaged with the least amount of waste, are made from recycled or recyclable materials and contain no hazardous substances. *

Dioxin: Any of a family of organic compounds known chemically as dibenzo-p-dioxins. Their potential toxicity and presence as contaminants in commercial products create concern. *

Discards: Include the municipal solid waste remaining after recovery for recycling and composting. These discards usually are combusted or disposed of in landfills, although some MSW is littered, stored or disposed of on site, particularly in rural areas. **

Disposal: The activities associated with the long-term handling of (1) solid wastes that are collected and are of no further use and (2) the matter that remains after solid wastes have been processed and the recovery of conversion products or energy has been accomplished. Normally, disposal is accomplished by sanitary landfilling. ${ }^{* *}$

Disposal Facility: A collection of equipment and an associated land area that receives waste and disposes of it. The facility may incorporate one or more disposal methods. **

Diversion Rate: A measure of the amount of material now being diverted from landfilling for reuse and recycling, compared with the total amount of waste that previously was discard. ${ }^{* *}$ 
Drop-Off Center: A location where residents or businesses bring source-separated recyclable materials. Drop-off centers range from single-material collection points to staffed, multimaterial collection centers. **

Effluent: Wastewater, treated or untreated, that flows out of a treatment plant, sewer or industrial outfall. Generally refers to wastes discharged into surface waters. *

Energy Recovery: The conversion of solid waste into energy or a marketable fuel. A form of resource recovery in which the organic fraction of waste is converted to some form of usable energy, such as burning processed or raw refuse to produce steam. ${ }^{* *}$

Environmental Impact Statement: A document required of federal agencies by the National Environmental Policy Act for major projects or legislative proposals that significantly affect the environment. A tool for decision making, it describes the positive and negative effects of the undertaking and cites alternative actions. * Individual states also may prepare and issue an EIS as regulated by state law. Such state documents may be called environmental impact reports (EIR). **

Environmental Quality: The overall health of an environment determined by comparison with a set of standards. ${ }^{* *}$

EPA: The U.S. Environmental Protection Agency is a federal agency that was created in 1970 and charged with the enforcement of all federal regulations having to do with air and water pollution, radiation and pesticide hazard, ecological research and solid waste disposal. **

Facility Operator: Contractors or other operators of a part of a solid waste management facility. **

Flow Control: A legal or economic means by which waste is directed to particular destinations; for example, an ordinance requiring that certain wastes be sent to a specific facility or combination of facilities.

Food Wastes: Animal and vegetable wastes resulting from the handling, storage, sales, preparation, cooking and serving of foods. **

Full Material Recovery Facility: A process for removing recyclables and creating a compost-like product from the total mixed municipal solid waste (MSW) stream. Differs from a "clean" MRF, which processes only commingled reyclables. ${ }^{* *}$

Full Service Operator: A supplementary vendor that designs, finances and operates a solid waste management facility.

Garbage: The municipal solid waste remaining after source separation of recyclables, yard waste, household hazardous waste and bulky waste. *

Geographic Information System (GIS): A computer system designed to store, manipulate, analyze, and display data in a geographic context. *

Haulers: Those persons, firms, corporations or government agencies that are responsible (under either oral or written contract or otherwise) for the collection of solid waste within the geographic boundaries of the contract community or the incorporated county and for the transportation and delivery of such solid waste to the resource recovery system as directed in the plan of operations. ${ }^{* *}$

Hazardous Waste: By-products of society that can pose a substantial or potential hazard to human health or the environment when improperly managed. Possesses at least one of four characteristics (ignitability, corrositivty, reactivity or toxicity) or appears on special EPA lists.*

High-Risk Community: A community located within the vicinity of numerous facilities or other potential sources of environmental exposure for health hazards that may result in high levels of exposure to contaminants or pollutants. *

Household Hazardous Wastes: Those wastes resulting from products purchased by the general public for household use that, because of their quantity, concentration, or physical, chemical or infectious characteristics, may pose a substantial known or potential hazard to human health or the environment when improperly treated, disposed or otherwise managed. ** 
Industrial Waste: Materials discarded from industrial operations or derived from industrial operations or manufacturing processes and from all nonhazardous solid wastes other than residential, commercial and institutional. Industrial waste includes all wastes generated by activities such as demolition and construction, manufacturing, agricultural operations, wholesale trade and mining. A distinction should be made between scrap (those materials that can be recycled at a profit) and solid wastes (those that cannot economically be reclaimed). ${ }^{* *}$

Inorganic Material: Not composed of once-living material (e.g., minerals); generally, composed of chemical compounds not principally based on the element carbon.**

Integrated Waste Management: The practice of using a variety of methods to handle municipal solid waste; can include source reduction, recycling, incineration and landfilling. *

Investment Tax Credit: A reduction in taxes that is permitted for purchase and installation of specific types of equipment and other investments. ${ }^{* *}$

Leachate: Water that collects contaminants as it trickles through wastes, pesticides or fertilizers. Leaching may occur in farming areas, feedlots and landfills and may result in hazardous substances entering surface water, groundwater or soil. *

Litter: The highly visible portion of solid waste that is carelessly discarded outside the regular garbage and trash collection and disposal system. *

Magnetic Separation: Use of magnets to separate ferrous materials from the mixed municipal waste stream. *

Mandatory Deposit: A fee assessed on a good, usually at the point of sale. The deposit is refundable upon the return of the item or its container. Mandatory deposits are used to encourage recycling of the good in question and to offset disposal costs. Beverage container deposit laws are an example of mandatory deposits.

Mandatory Recycling: Programs that, by law, require consumers to separate trash so that some or all recyclable materials are recovered for recycling rather than going to landfills or waste-to-energy facilities. *

Manual Separation: Hand sorting of recyclable or compostable materials in waste. *

Materials Recovery Facilities: Multipurpose facilities that may include the functions of a drop-off center for separated wastes, a materials recovery facility, a facility for composting and bioconversion of wastes, a facility for the production of refuse-derived fuel and a transfer and transport facility. ${ }^{* *}$

Mechanical Separation: Using mechanical means to separate waste into various components.*

Methane: An odorless, colorless, flammable, asphyxiating gas that can explode under certain circumstances. It can be produced when solid wastes undergo anaerobic decomposition. Methane emitted from municipal solid waste landfills can be used as a fuel. **

Mulch: Any material, organic or inorganic, applied as a top layer to the soil surface. Mulch also is placed around plants to limit evaporation of moisture and freezing of roots and to nourish the soil. **

Municipal Solid Waste (MSW): Includes nonhazardous solid wastes from residential, commercial, institutional and limited industrial sources. MSW generally is composed of durable goods, nondurable goods, containers and packaging and other wastes such as yard trimmings and food.

National Ambient Air Quality Standards (NAAQS): Federal standards that limit the concentration of particulates, sulfur dioxide, nitrogen dioxide, ozone, carbon monoxide and lead in the atmosphere.**

National Emissions Standards for Hazardous Air Pollutants (NESHAPS): Emissions standards set by EPA for an air pollutant not covered by NAAQS that may cause an increase in fatalities or in serious, irreversible or incapacitating illness. Primary standards are designed to protect human health; secondary standards protect public welfare (e.g., building facades, visibility, crops and domestic animals). *

NIMBY (not in my backyard): Refers to the fact that people want the convenience of products and proper disposal of the waste generated by their use of products, provided the disposal area is not located near them. ${ }^{* *}$ 
Nonrenewable (resource): Not capable of being naturally restored or replenished; resources available in a fixed amount (stock) in the earth's crust; they can be exhausted either because they are not replaced by natural processes or because they are replaced more slowly than they are used. **

Organic Materials: Chemical compounds containing carbon, excluding carbon dioxide, combined with other chemical elements. Organic materials can be of natural or anthropogenic origin. Most organic compounds are a source of food for bacteria and usually are combustible. ${ }^{* *}$

Packaging: Any of a variety of plastics, papers, cardboard, metals, ceramics, glass, wood and paperboard used to make containers for food and household and industrial products. ${ }^{* *}$

Performance Data: Information collected during a trial burn on concentrations of designated organic compounds and pollutants found in incinerator emissions. Data analysis must show that the incinerator meets performance standards under operating conditions specified in its RCRA permit.*

Plastics: Nonmetallic, chemoreactive compounds molded into rigid or pliable construction materials, fabrics, and so on. *

Point of Generation: The physical location where the generator discards material (mixed refuse or separated recyclables). **

Pollutant: Dredged spoil, solid waste, incinerator residue, sewage, garbage, sewage sludge, munitions, chemical wastes, biological materials, radioactive materials, heat, wrecked or discarded equipment, rock, sand, cellar dirt and industrial, municipal and agricultural waste discharged into the environment. Any solid, liquid or gaseous matter that is in excess of natural levels or established standards. **

Pollution Prevention: The active process of identifying areas, processes and activities that create excessive waste byproducts or pollutants for the purpose of substitution, alteration or elimination of the process to prevent waste and pollutant generation. *

Postconsumer Recycling: The reuse of materials generated from residential and commercial waste, excluding recycling of materials from industrial processes that have not reached the consumer, such as glass broken in the manufacturing process. ${ }^{* *}$

Preconsumer Recycling: The reuse of materials generated from industrial processes that have not yet reached the consumer. For example, paper trimmed from a good as a final step in production.

Precycling: Activities such as source and size reduction, material selection when shopping and reducing toxicity of products in manufacturing before recycling help reduce the overall amount of solid waste generated. **

Privatization: The assumption of responsibility for a public service by the private sector, under contract to local government or directly to the receivers of the service. ${ }^{* *}$

Product: Wares, commodities, merchandise or goods used to satisfy human wants or needs. ****

Program: The full range of source reduction, recycling, composting, special waste or household hazardous waste activities that are undertaken by or in the jurisdiction or relating to management of the jurisdiction's waste stream to achieve the objectives identified in the integrated waste management approaches. ${ }^{* *}$

Public Comment Period: The time allowed for the public to express its views and concerns regarding an administrative action (e.g., an executive agency or board rule-making or a public notice of a draft permit).

Public Hearing: A formal meeting where officials hear the public's views and concerns about an administrative action or proposal. Most agencies are required to consider such comments when evaluating their actions. Public hearings may be held upon request during the public comment period.

Public Notice: Notification by EPA informing the public of agency actions such as the issuance of a draft permit or scheduling of a hearing. EPA is required to ensure proper public notice, including publication in newspapers and broadcast media. *

Rate Structure: That set of prices established by a jurisdiction, special district (as defined in Government Code section 56036) or other rate-setting authority to compensate the jurisdiction, special district or rate-setting 
authority for the partial or full costs of the collection, processing, recycling, composting transformation or landfill disposal of solid wastes. **

RCRA (pronounced rick-rah) Resource Conservation and Recovery Act of 1976: Requires states to develop solid waste management plans and prohibits open dumps. Identifies lists of hazardous wastes and sets the standards for their disposal. This law amends the Solid Waste Disposal Act of 1965 and expands on the Resource Recovery Act of 1970 to provide a program to regulate solid and hazardous waste and underground storage tanks. Codified at 42 USC 6401, et seq.

Recovery: The extraction of useful materials or energy from waste. Refers to materials removed from the waste stream for the purpose of recycling or composting. Recovery does not automatically equal recycling and composting however. For example, if markets for recovered materials are not available, the materials that were separated from the waste stream for recycling may simply be stored or, in some cases, sent to a landfill or combustor.**

Recyclables: Discarded materials that can be collected, sorted, processed and then used as raw materials in the production of new products. New products do not include materials that are used as fuel substitutes or for energy production. $* * * * *$

Recycling: A four-step process involving separation of a waste material from the waste stream, collection (before or after separation), processing and use of that waste material as the raw material for products that may or may not be similar to the original. All four steps are critical for a material to be considered recycled.

Refuse: All solid materials that are discarded as useless. A term often used interchangeably with the term "solid waste." **

Rejects: Materials that cannot be processed, burned or recycled and that must be turned away from the incinerator, recycling facility or composting facility for disposal. ${ }^{* * *}$

Residuals or Residue: Amount of a pollutant remaining in the environment after a natural or technological process has taken place. For example, ash is a residual of the incineration process. *

Resource Recovery: The process of obtaining matter or energy by extracting useful materials or energy from municipal solid waste. ${ }^{* * *}$

Energy Recovery: Extracting useful energy from solid waste. ${ }^{* * *}$

Materials Recovery: Extracting useful materials from solid waste. ${ }^{* * *}$

Reuse: The use of a product more than once in its same form for the same purpose. For example, a soft drink bottle is reused when it is returned to the bottling company for refilling. *

Risk Assessment: Qualitative and quantitative evaluation of the risk posed to human health or the environment by the actual or potential presence or use of specific pollutants. *

Risk Characterization: During this last step in the risk assessment process the potential for adverse health effects is characterized and the degree of uncertainty involved is evaluated. *

Sanitary Landfill: An engineered method of disposing of solid wastes on land in a manner that protects human health and the environment. Waste is spread in thin layers, compacted to the smallest practical volume and covered with soil or other suitable material at the end of each working day or more frequently, as necessary. Sanitary landfills commonly are lined and equipped for collection of leachate for treatment. **

Scrap: Products that have completed their useful life, such as appliances, cars and construction materials. It also includes new scrap materials that result as by-products when metals are processed and products are manufactured. $* *$

Scrubber: A device for removing unwanted dust particles, liquids or gaseous substances from an airstream by spraying the airstream with a liquid (usually water or a caustic solution) or forcing the air through a series of baths. This common antipollution device uses a liquid or slurry spray to remove acid gases and particulates from municipal waste combustion facilities flue gases. ${ }^{* *}$ 
Secondary Materials: Materials that have been manufactured and used at least once and are to be used again. *

Separate Collection: Collection from households of recyclable or compostable materials that have been separated before collection. The separate collection can be done using refuse vehicles or specialized vehicles. ${ }^{* * *}$

Separation: To divide wastes into groups of similar material, such as paper products, glass, food wastes and metals. Also used to describe the further sorting of materials into more specific categories, such as clear glass and green glass. Separation can be done manually or mechanically. ${ }^{* *}$

Sludge: A semiliquid residue remaining from the treatment of municipal and industrial water and wastewater; consists of suspended solids combined with water and dissolved material in varying amounts. ${ }^{* * *}$

Solid Waste: Nonliquid, nonsoluble materials ranging from municipal garbage to industrial wastes that contain complex and sometimes hazardous substances. Solid wastes also include sewage sludge, agricultural refuse, demolition wastes and mining residues. Technically, solid waste also refers to liquids and gases in containers.*

Solid Waste Disposal Facility: Any solid waste management facility that is the final resting place for solid waste, including landfills and combustion facilities that produce ash from the process of incinerating municipal solid waste. ${ }^{* *}$

Source Reduction: Reduction of the amount of materials that enter the waste stream by voluntary or mandatory programs to eliminate the generation of waste. The design, manufacture, acquisition and reuse of materials to minimize the toxicity of the waste generated. ** Also known as waste reduction.

Special Wastes: Special wastes include bulky items, consumer electronics, white goods, yard wastes that are collected separately, hazardous wastes, concrete, batteries, used oil, asphalt and tires. Special wastes usually are handled separately from other residential and commercial wastes. ${ }^{* *}$

Subtitle C: The hazardous waste section of the Resource Conservation and Recovery Act (RCRA)**

Subtitle D: The solid, nonhazardous waste section of the Resource Conservation and Recovery Act (RCRA). **

Subtitle F: Section of the Resource Conservation and Recovery Act (RCRA) requiring the federal government to actively participate in procurement programs fostering the recovery and use of recycled materials and energy.**

Superfund: The program operated under the legislative authority of the Comprehensive Environmental Response Compensation and Liability Act (CERCLA) [42 USC 9601, et seq.] and the Superfund Amendments and Reauthorization Act of 1986 (SARA) that funds and authorizes cleanup of abandoned and inactive contamination sites. These activities include establishing the National Priorities List, investigating sites for inclusion on the list, determining their priority and conducting or supervising the cleanup and other remedial actions. *

Tipping Fee: A fee, usually dollars per ton, for the unloading or dumping of waste at a landfill, transfer station, recycling center or waste-to-energy facility. Also called a disposal or service fee. ${ }^{* *}$

Transfer Station: A place or facility where wastes are transferred from smaller collection vehicles (e.g., compactor trucks) into larger transport vehicles (e.g., over-the-road and off-road tractor trailers, railroad gondola cars or barges) for movement to disposal areas, usually landfills. In some transfer operations, compaction or separation may be done at the station. **

Trash: Wastes that usually do not include food wastes but may include other organic materials. Generally defined as dry waste material; in common usage it is a synonym for rubbish or refuse. ${ }^{* *}$

Vectors: An organism, often an insect or rodent, that carries disease.*

Virgin Material: Any basic material for industrial processes that has not previously been used; for example, woodpulp trees, iron ore, silica sand, crude oil and bauxite. ${ }^{* *}$

Volume: A three-dimensional measurement of the capacity of a region of space or a container. Volume commonly is expressed in cubic yards or cubic meters, not mass or weight. ** 
Volume-Based Rates: A system of charging the waste generator for garbage pickup based on the volume of waste collected. The greater the volume of waste collected, the higher the charge. "Pay-as-you-throw" systems and variable rates are examples of volume-based rates. ${ }^{* *}$

Volume Reduction: Processing MSW that requires final disposal to reduce volume; for example, waste-to-energy facilities can reduce MSW volume by 90 percent.

Waste Categories: The grouping of solid wastes with similar properties into major solid waste classes. For example, grouping office paper, corrugated paper and newspaper under a paper waste category. ${ }^{* *}$

Waste Diversion: To divert solid waste, in accordance with all applicable federal, state and local requirements, from disposal at solid waste landfills or transformation facilities through source reduction, recycling or composting. ${ }^{* *}$

Waste Minimization: Measures or techniques that reduce the amount of wastes generated during industrial production processes; this term also is applied to recycling and other efforts to reduce the amount of waste going into the waste stream. *

Waste Reduction: The prevention or restriction of waste generation at its source by redesigning products or changing the patterns of production and consumption. **

Waste Stream: A term describing the total flow of solid waste from homes, businesses, institutions and manufacturing plants that must be recycled, burned or disposed of in landfills, or any segment thereof, such as the "residential waste stream" or the "recyclable waste stream." The total waste produced by a community, from origin to disposal. ${ }^{* *}$

Water Table: Level below the earth's surface at which the ground becomes saturated with water. Landfills and composting facilities are designed in accordance with the water table to minimize potential contamination. **

Weight-Based Rates: A system of charging for garbage pickup based on weight of the garbage collected. The greater the weight, the higher the charge. The logistics of implementing this system currently are being developed.

Wetlands: An area that is saturated by surface or groundwater, with vegetation adapted for life under those soil conditions, as in swamps, bogs, fens, marshes and estuaries. *

White Goods: Large worn-out or broken household, commercial and industrial appliances, such as stoves, refrigerators and dishwashers. ${ }^{* *}$

Windrow: A large, elongated pile of composting material. **

Yard Wastes: Leaves, grass clippings, prunings and other natural organic matter discarded from yards and gardens. Yard wastes also may include stumps and brush, but these materials normally are not handled at composting facilities. **

* U.S. Environmental Protection Agency. Terms of Environment: Glossary, Abbreviations, and Acronyms. Washington, D.C.: Revised April 1994.

** Kreith, Frank. Handbook of Solid Waste Management. New York: McGraw-Hill, Inc., 1994.

*** Kreith, Frank. Solid Waste Management: 1989-1990 State Legislation. Denver: National Conference of State Legislatures, 1990.

**** Webster's Ninth New Collegiate Dictionary. Springfield, Mass.: Merriam-Webster Inc., 1991.

*****Definitions approved by the National Recycling coalition Board of Directors, Sept. 10, 1995. 


\section{SELECTED RefERENCES}

Aquino, John T. "Landfill Reclamation Attracts Attention and Questions." Waste Age (December 1994): 63-68.

Aquino, John T. and Cheryl McAdams. "Dioxin: Impact on Solid Waste Industry Uncertain." Waste Age (November 1994): 106.

Artz, Nicholas S., and Jacob E. Beachey. "Financing and Life-Cycle Costing of Solid Waste Management Systems." In Handbook of Solid Waste Management, edited by Frank Kreith, 14.6. New York: McGraw-Hill, 1994.

Barlaz, M. A., R. Ranjithan, et al. Developing a Life-Cycle Inventory of Municipal Solid Waste Management

Alternatives. Research Triangle, N.C.: Research Triangle Institute, 1995.

Berenyi, Eileen B., Ph.D. "Methane Recovery from Landfills Makes a Comeback." Waste Age (September 1994): 107-114.

Berman, E. B. WRAP, A Model for Regional Solid Waste Management Planning: User's Guide. Washington, D.C.:

U.S. Environmental Protection Agency, 1977.

Brunner, P. H., and W. R. Ernst. "Alternative Methods for the Analysis of Municipal Solid Waste." Waste

Management and Research 4, 1986, 147-160.

Council on Plastics and Packaging in the Environment. "Composting." COPPE INFO BACKGROUNDER (May 1991).

Davis, S. S. "Financing a Recycling/MSW Composting Facility." Biocycle, 33 no. 2 (1992): 54-56.

Denison, Richard A.; John Ruston; Jeffrey Tryens and Roger Diedrich. "Environmental Perspectives." In Handbook of Solid Waste Management, edited by Frank Kreith, 7.13. New York: McGraw-Hill, 1994.

Diaz, L. F.; G. M. Savage and C. G. Golueke. "Composting of Municipal Solid Wastes." In Handbook of Solid Waste Management, edited by Frank Kreith, 10.4. New York: McGraw-Hill, 1994.

Environment Canada. The National Incinerator Testing and Evaluation Program. Canada, March 1991.

Environment Canada. Office of Waste Management 1990 - 1992. Canada, Nov. 28, 1992.

Environment Canada. Summary Report: The National Pollutant Release Inventory. Canada 1993.

Environment Canada and The Composting Council of Canada. National Survey of Composting Operations in

Canada. 2nd Edition Canada, May 1995.

Executive Order 12873, October 20, 1993.

Franklin \& Associates. The Role of Recycling in Integrated Solid Waste Management to the Year 2000. Prepared for Keep America Beautiful, Stamford, Conn., September 1994.

Franklin, Majorie A. "Solid Waste Stream Characteristics." In Handbook of Solid Waste Management, edited by

Frank Kreith, 3.13. New York: McGraw-Hill, 1994.

Frantzis, I. "Methodology for Municipal Landfill Sites Selection." Waste Management and Research 11 (1993): $441-451$.

Hagevik, George. "Pollution Prevention." NCSL Legisbrief (Denver, Colo.: National Conference of State

Legislatures) 3, no. 2 (January 1995).

Hagg-Nelson, Laura. "State Approaches to Handling White Goods Recycling." Testimony prepared for the Public Hearing on the Enforcement of Litter Laws and the Recycling of White Goods, Joint Legislative Conservation

Committee for the Pennsylvania General Assembly, April 20, 1995.

Hasselriis, Floyd. "Ash Disposal." In Handbook of Solid Waste Management, edited by Frank Kreith, 11.100-2.

New York: McGraw-Hill, 1994.

Heijungs, R. Environmental Life Cycle Assessment of Products Backgrounds_-October 1992. final ed., [translated from the Dutch by TechTrans]. Leiden, the Netherlands: Multicopy, 1992.

Heijungs, R. Environmental Life Cycle Assessment of Products: Guide-October 1992. final ed., [translated from the Dutch by TechTrans]. Leiden, the Netherlands: Multicopy, 1992. 
Jessup, Deborah Hitchcock. Waste Management Guide: Laws, Issues \& Solutions. The Bureau of National Affairs, Washington, D.C., 1992, 255-257.

Kelly, Elizabeth, and Kristen Mellott. "Source Reduction Measurement: Round Table Report." Meeting Proceedings, Center for Policy Alternatives, February 1995.

Klee, A. ). PROTOCOL-A Computerized Solid Waste Quantity and Composition Estimation System. Washington,

D.C.: U.S. Environmental Protection Agency, National Renewable Energy Laboratory, 1992.

Kreith, Frank, ed. Handbook of Solid Waste Management. New York: McGraw-Hill, 1994, 1.6.

Kundell, James E., and Deanna L. Ruffer. "Planning MSW Management Programs." in Handbook of Solid Waste

Management, edited by Frank Kreith, 6.11-6.12. New York: McGraw-Hill, 1994.

Kundell, James E., and Deanna L. Ruffner. "Planning MSW Management Programs." In Handbook of Solid Waste

Management, edited by Frank Kreith, 6.13. New York: McGraw-Hill, 1994.

Kundell, James E.; Deanna L. Ruffner; and Steffney Thompson. "Solid Waste Flow Control (Designation)." A paper presented at the Conference of Southern County Associations' Regional Solid Waste/Environmental Network, March 1993, 3.

Kulik, A. "Europe Implements Variable Rates to Reduce Generation." World Wastes 36 no. 4 (1993) 14-16.

Leavitt, C. "Calculating the Costs of Waste management." World Waste, 37 no. 4 (1994) 42-50.

Logsdon, G. "Financing Solid Waste Systems." BioCycle 31 no. 3 (1990) 35.

Malloy, Michael, and Cheryl McAdams. "The U.S. and International Municipal Waste Combustion Industry." Waste

Age (November 1994): 92.

Managing America's Garbage. Golden, Colo.: National Renewable Energy Laboratory, March 1996.

Miller, Chaz. "Recycling in the States: 1994 Update." Waste Age (March 1995): 93.

Morandi, Larry, and Sam Azodmanesh. "Financing Water Quality Infrastructure: An Update on State Revolving

Funds." NCSL State Legislative Report (Denver, Colo.: National Conference of State Legislatures) 17, no. 20

(October 1992): 5.

Murphy, Mary Ellen, and Marc J. Rogoff. "Court's Ash Decision Raises Questions: States Have Answers." Solid

Waste Technologies (September/October 1994): 12-17.

National Environmental Law Center, et al. States Close the Loop: A Survey of Recycled Content Laws and Other

Market Development Strategies. Portland, Ore.: NELG, Nov. 1993.

National Recycling Coalition. 1994-95 Market Development Directory. Washington, D.C., 1994.

National Recycling Coalition, Issue Paper Subcommittee on Economics/Full Cost Accounting NRC Policy Research

Committee, Alexandria, Va. (Sept. 6, 1995).

Ossenbruggen, P. J., and P. C. Ossenbruggen. "SWAP: A Computer Package for Solid Waste Management."

Computing in Environmental and Urban Systems 16 (1992) 83-100.

Parker, Bruce. "Supreme Court Finds Clarkstown Flow Control Law Unconstitutional." Waste Age (June 1994): 21.

Proctor \& Redfern Ltd. Estimation of the Effects of Various Municipal Waste Management Strategies on Greenhouse

Gas Emissions: Part I. Ontario, Canada (September 1993).

Purtell, Lisa. Steel Recycling Institute. Personal communication, Oct. 26, 1995.

Rahenkamp, Kristen. "Incineration-A Technical Discussion for Lay Persons." In Integrated Solid Waste

Management, edited by Frank Kreith, appendix G. Schenectady, N.Y.: Genium Publishing Corp., 1990.

Redd, A. "Regional Systems Bring States Spotted Successes." World Wastes 36 no. 8 (1993) 68-72.

Rigo, H. Gregor. "Sources of Dioxin in the Environment." Solid Waste Technologies (January/February 1995): 3639.

The Solid Waste Association of North America. Integrated Municipal Solid Waste Management (IMSWM): Six Case Studies of System Costs and Energy Use. Silver Springs, Md.: SWANA, Nov. 1995. 
Southern States Waste Management Coalition. Integrated Management of Municipal Solid Waste: A Handbook for Local Officials. Norcross, Ga.: Southern States Energy Board, 1995.

Spencer, Robert. "New Approaches to Recycling Tires." BioCycle (March 1991) 34.

Steuteville, Robert. "The Market Turnaround: Year End Review of Recycling." BioCycle (December 1994) 30-31.

Steuteville, Robert. "Measuring the Impact of Disposal Bans." BioCycle 35 no. 9 (1994) 58-60.

Steuteville, Robert. "The State of Garbage in America." BioCycle (May 1995) 30, 36.

Steuteville, Robert. "The State of Garbage in America." BioCycle (April 1995) 54.

Steuteville, Robert. "Year End Review of Recycling." BioCycle (December 1994) 30-32.

Suskind, Lawrence, and David Laws. "Siting Solid Waste Facilities in the United States." In Handbook of Solid Waste Management, edited by Frank Kreith, 13.5. New York: McGraw-Hill, 1994.

Tanner, Arnold O. "Materials Recycling/Annual Report." U.S. Department of the Interior, Bureau of Mines (Washington, D.C., 1993).

U.S. Environmental Protection Agency. Characterization of Municipal Solid Waste in the United States: 1994 Update (Washington, D.C., 1994), 3.

U.S. Environmental Protection Agency. Criteria for Solid Waste Disposal Facilities: A Guide for Owners/Operators. (Washington, D.C., March 1993).

U.S. Environmental Protection Agency. Decision-Makers' Guide To Solid Waste Management. (Washington, D.C., November 1989), 117, 121, 126.

U.S. Environmental Protection Agency. Report to Congress on Flow Control and Municipal Solid Waste: Executive Summary. (Washington, D.C., March 1995).

U.S. Environmental Protection Agency. Sites for Our Solid Waste: A Guidebook for Effective Public Involvement. (Washington, D.C., March 1990), 27.

U.S. Environmental Protection Agency. The Solid Waste Dilemma: An Agenda for Action. (Washington, D.C., February 1989), 16.

U.S. Environmental Protection Agency, Office of Pollution Prevention and Toxics. Executive Order on Federal Acquisition, Recycling and Waste Prevention: Status of Section 503 Implementation Guidance for Environmentally Preferable Products and Services. (Washington, D.C., October 1994).

U.S. Environmental Protection Agency, Office of Research and Development. Environmental Economic and Energy Impacts of Material Recovery Facilities: A MITE Program Evaluation. (Washington, D.C., September 1995).

U.S. Environmental Protection Agency, Office of Research and Development. Household Hazardous Waste Characterization Study for Palm Beach County, Florida: A MITE Program Evaluation, (Washington, D.C., September 1995).

U.S. Environmental Protection Agency, Region III. Recycling Markets, Marketing and Market Development: A Primer for Government Officials. (Philadelphia, Pa., 1993), 3.

U.S. Department of the Interior, Bureau of Mines. Annual Report: Annual Solid Waste Generation in the United States. (Washington, D.C., 1995).

U.S. General Accounting Office. Government Auditing Standards: 1994 Revision. (Washington, D.C., 1994$), 14$.

U.S. General Accounting Office. Pollution Prevention: EPA Should Reexamine the Objectives and Sustainability of State Programs. (Washington, D.C., January 1994), 3.

University of Illinois at Chicago. "Central Facility Composting." Solid Waste Management 7 no. 11 (Chicago, III., November 1993).

University of Illinois at Chicago. "Municipal Solid Waste Combustion." Solid Waste Management 8 no. 2 (Chicago, III., March 1994).

University of Illinois at Chicago. "Municipal Solid Waste Landfills: Overview and Environmental Impacts." Solid Waste Management 7 no. 12 (Chicago, Ill., December 1993). 
van den Berg, N. W.; C. E. Dutilh; and G. Huppes. Beginning LCA: A Guide Into Environmental Life Cycle Assessment. The Netherlands: National Reuse of Waste Research Program, February 1995.

Vasuki, N. C. "Competition in the Solid Waste Industry." MSW Management (March/April 1996).

Williams, Marcia. "Integrated Municipal Solid Waste Management." in Handbook of Solid Waste Management, edited by Frank Kreith, 2.3. New York: McGraw-Hill, 1994.

Williams, Marcia E.. "Integrated Solid Waste Management." In Integrated Solid Waste Management: Options for State Legislative Action, edited by Frank Kreith, 10. Schenectady, N.Y.: Genium Publishing Corporation, 1990. Woods, Randy, and John T. Aquino. "Congress Moves Forward on Flow Control and Interstate; Study Predicts Higher Disposal Costs." Waste Age (June 1995) 10.

The World Resource Foundation. Landfill Mining, technical brief (Kent, U.K.; The World Resource Foundation ind.) $1-8$.

The World Resource Foundation. Landfill Techniques, technical brief (Kent, U.K.; The World Resource Foundation ind.) $1-8$.

Yee, Adelia. "Risk Assessment: A Glance at the Non-Technical Aspects." NCSL State Legislative Report (Denver, Colo.: National Conference of State Legislatures) 19, no. 18 (November 1994). 


\section{Selected Trade Publications and On-Line Resources}

\section{Trade Publications}

BioCycle: Journal of Composting and Recycling (610) $967-4135$

MSW Management: The Journal for Municipal Solid Waste Professionals (805) 681-1312

Recycling Today: The Business Magazine for Recycling Professionals (216) $961-4130$

Resource Recycling: North America's Recycling Journal

(503) 227-1319

Solid Waste Technologies

(913) 642-6032

Waste Age: The authoritative voice of waste systems and technology (202) $244-4700$

Waste Age's Recycling Times

(800) 829-5443

Waste Tech News: The newspaper for waste and pollution control industries (303) 628-0701

\section{On-Line Resources}

Chicago Board of Trade Recyclables Exchange Access Information http://www.cbot.com

Global Recycling Network

http://grn.com/grn/ora.html

The Solid Waste Group at the Tellus Institute http://www.channell.com/users/tellus/solid.html

Solid Waste Information System http://ksgwww.harvard.edu/swis/

U.S. Environmental Protection Agency Citizen Information http://www.epa.gov/

Waste Management Information http://www.acenet.auburn.edu:70/1s/waste_mgt 


\section{Selected Trade Associations}

Aluminum Recycling Association

100016 th St. NW, Suite 400

Washington, DC 20036

(202) 785-0951

(202) 785-0210 fax

American Plastics Council

1275 K Street, NW, Suite 400

Washington, DC 20005

(202) $371-5205$

(202) 371-5679 fax

Aseptic Packaging Council

1225 I St., NW, Suite 500

Washington, DC 20005

(202) 333-5900

(202) 333-5987 fax

Asphalt Recycling and Reclaiming Association 3 Church Cir., Suite 250

Annapolis, MD 21401

(202) 544-7111

(202) 544-7146 fax

Association of Foam Packaging Recyclers

1025 Connecticut Ave., NW, Suite 515

Washington, DC 20036

(202) 822-6424

(202) 331-0538 fax

Association of Petroleum Re-Refiners

PO Box 605, Ellicott Station

Buffalo, NY 14205-0605

(716) $855-2757$

(716) 855-0339 fax

Association of Post-Consumer Plastics

1040 Broad St., Suite 302

Shrewsbury, NJ 07702

(908) $542-7300$

(908) 542-9344 fax

Center for Plastics Recycling Research

Rutgers University, Bldg. 3529, PO Box 1179

Piscataway, NJ 08855

(908) 445-3679

(908) $932-5636$ fax
Container Recycling Institute

$710 \mathrm{G}$ Street, SE

Washington, DC 20003

(202) 543-9449

(202) $544-0410$ fax

Environmental Industries Association 4301 Connecticut Ave., NW Suite 300 Washington, DC 20008

(202) 244-4700

Glass Packaging Institute

1627 K St., NW, Suite 800

Washington, DC 20006

(202) $887-4850$

(202) 785-5377 fax

Grocery Manufacturers of America, Inc.

1010 Wisconsin Ave., NW, Suite 800

Washington, DC 20007

(202) $337-9400$

(202) $337-4508$ fax

National Association of Chemical Recyclers 1200 G St. NW, Suite 800

Washington, DC 20006

(202) 986-8150

(202) 393-2630 fax

National Office of Paper Recycling 1620 । St. NW

Washington, DC 20006

(202) 293-7330

(202) 293-2352 fax

National Recycling Coalition, Inc.

1727 King St., Suite 105

Alexandria, VA 22314-2720

(703) 683-9025

(703) 683-9026 fax

National Soft Drink Association

Environmental Affairs

1101 16th St., NW

Washington, DC 20036

(202) 463-6700

(202) 659-5349 fax 
Solid Waste Association of North America

PO Box 7219

Silver Spring, MD 20910-7219

(301) $585-2898$

(301) 589-7068 fax

Steel Recycling Institute

Foster Plaza No. $X$

680 Andersen Dr.

Pittsburgh, PA 15220

(800) 876-7274

(412) $922-3213$ fax
Tire Retread Information Bureau 900 Weldon Grove

Pacific Grove, CA 93950

(408) $372-1917$

(408) 372-9210 fax 